\title{
Lipids detection and quantification in oleaginous microorganisms: an overview of the current state of the art
}

\author{
Alok Patel ${ }^{\dagger}$, lo Antonopoulou ${ }^{\dagger}$, Josefine Enman, Ulrika Rova, Paul Christakopoulos and Leonidas Matsakas ${ }^{*}$ [D
}

\begin{abstract}
Oleaginous microorganisms are among the most promising feedstocks for the production of lipids for biofuels and oleochemicals. Lipids are synthesized in intracellular compartments in the form of lipid droplets. Therefore, their qualitative and quantitative analysis requires an initial pretreatment step that allows their extraction. Lipid extraction techniques vary with the type of microorganism but, in general, the presence of an outer membrane or cell wall limits their recovery. This review discusses the various types of oleaginous microorganisms, their lipid accumulating capabilities, lipid extraction techniques, and the pretreatment of cellular biomass for enhanced lipid recovery. Conventional methods for lipid quantification include gravimetric and chromatographic approaches; whereas nonconventional methods are based on infrared, Raman, nuclear magnetic resonance, and fluorescence spectroscopic analysis. Recent advances in these methods, their limitations, and fields of application are discussed, with the aim of providing a guide for selecting the best method or combination of methods for lipid quantification.
\end{abstract}

Keywords: Oleaginous microorganisms, Microbial lipids, Lipid extraction, Lipid quantification, Conventional methods, High-throughput analysis

\section{Introduction}

In the search for alternatives to fossil-derived oils, oleaginous microorganisms have attracted attention as potential sources of oil feedstocks. Microalgae, yeasts, fungi, and bacteria, can accumulate high amounts of lipids ( $>20 \%$ of cell dry weight) in their cellular compartments and are considered as oleaginous feedstocks for biofuel production [1]. A list of oleaginous microorganisms and their lipid accumulation ability is presented in Table 1 .

Under nutrient-limiting conditions combined with an excess of carbon, oleaginous microorganisms accumulate significant quantities of lipids known as single cell oils $[24,25]$. These lipids are composed predominantly of neutral triacylglycerols (TAGs), energy-rich fatty acids that can be used for biodiesel production. Depending on fatty acid composition, which is highly variable between species and strains, these lipids are suitable as raw

\footnotetext{
* Correspondence: leonidas.matsakas@ltu.se

${ }^{\dagger}$ Alok Patel and lo Antonopoulou contributed equally to this work. Biochemical Process Engineering, Division of Chemical Engineering, Department of Civil, Environmental, and Natural Resources Engineering, Luleå University of Technology, SE-971 87 Luleå, Sweden
}

materials for the food, pharmaceutical, nutraceutical, and cosmetic industries [26, 27].

Although oleaginous microorganisms are an attractive and renewable feedstock, the cost associated with microbial lipid production needs to be kept low. Consequently, the challenge for robust and cost-competitive microbial lipid production systems is to develop strains that are capable of converting low-cost substrates, grow quickly to high cell densities, and produce large amounts of neutral lipids [9]. This involves the identification of organisms with an inherent lipid accumulation capacity, as well as their genetic/metabolic engineering to direct carbon flow towards increased lipid biomass or to cope with adverse growth conditions on various carbon sources [28, 29]. Exploration of candidate microorganisms and establishment of favourable cultivation conditions often relies on laborious and time-consuming screening processes. Moreover, the analysis of a large number of samples generated from a screening assay represents a major bottleneck. Fast and accurate quantification of accumulated lipids is key to address this issue. Conventional methods for lipid quantification rely on

(c) The Author(s). 2019 Open Access This article is distributed under the terms of the Creative Commons Attribution 4.0 International License (http://creativecommons.org/licenses/by/4.0/), which permits unrestricted use, distribution, and 
Table 1 Examples of oleaginous microorganisms and their lipid accumulating capability on various feedstocks

\begin{tabular}{|c|c|c|c|}
\hline Oleaginous microorganisms & Substrates & $\begin{array}{l}\text { Lipid content } \\
(\%, w / w)\end{array}$ & References \\
\hline \multicolumn{4}{|l|}{ Microalgae } \\
\hline Chlorella sorokiniana & Beech wood Fagus sylvatica dilute-acid hydrolysate & 4 & {$[2]$} \\
\hline Chlorella protothecoides & Glucose & 49 & [3] \\
\hline Tetraselmis elliptica & Photoautotrophic (Flory medium) & 14 & {$[4]$} \\
\hline Chlorella vulgaris NIES-227 & Heterotrophic cultivation on glucose under nitrogen limitation & 89 & {$[5]$} \\
\hline Auxenochlorella protothecoides & Organosolv pretreated wood biomass hydrolysates (birch and spruce) & 66 and 63 & {$[6]$} \\
\hline Botryococcus braunii & Photoautotrophic (modified Chu 13 medium) & 28 & {$[7]$} \\
\hline Chlamydomonas reinhardtii, CC1010 & Photoheterotrophic (TAPN ${ }^{-}+0.1 \%$ glucose) & 59 & {$[8]$} \\
\hline \multicolumn{4}{|l|}{ Yeast } \\
\hline Rhodosporidium toruloides & Brewers' spent grain & 56 & {$[9]$} \\
\hline Lipomyces starkeyi & Xylose and glucose & 48 & {$[10]$} \\
\hline Rhodotorula glutinis & Monosodium glutamate with glucose & 20 & {$[11]$} \\
\hline \multirow[t]{2}{*}{ Cryptococcus curvatus } & Waste cooking oil & 70 & {$[12]$} \\
\hline & Glucose & 53 & \\
\hline Lipomyces starkeyi CBS 1807 & Sweet sorghum stalks juice & 30 & [13] \\
\hline \multicolumn{4}{|l|}{ Fungi } \\
\hline \multirow[t]{5}{*}{ Fusarium oxysporum } & Sweet sorghum stalks ( $12 \%$ w/w solid load) & 22 & {$[14]$} \\
\hline & Glucose & 42 & \\
\hline & Fructose & 26 & \\
\hline & Sucrose & 49 & \\
\hline & Glucose, fructose and sucrose mixture & 53 & \\
\hline Fusarium equiseti UMN-1 & Glucose & 56 & {$[15]$} \\
\hline Sarocladium kiliense ADH17 & Glucose and glycerol & 33 & {$[16]$} \\
\hline Mortierella alpina LP M 301 & Glucose with potassium nitrate & 31 & {$[17]$} \\
\hline Microsphaeropsis sp. & Corncob waste liquor & 22 & {$[18]$} \\
\hline \multicolumn{4}{|l|}{ Bacteria } \\
\hline Rhodococcus opacus DSM 1069 & Ethanol organosolv lignin & 4 & {$[19]$} \\
\hline \multirow[t]{2}{*}{ R. opacus PD630 } & Dairy wastewater & 14 & {$[20]$} \\
\hline & Dextrose & 70 & \\
\hline R. opacus DSM 43205 & Biomass gasification wastewater & 66 & {$[21]$} \\
\hline \multirow[t]{6}{*}{ Gordonia sp. DG } & Olive oil & 13 & {$[22]$} \\
\hline & Sesame oil & 50 & \\
\hline & Cotton oil & 50 & \\
\hline & Peanut oil & 40 & \\
\hline & Maize oil & 40 & \\
\hline & Sunflower oil & 52 & \\
\hline R. opacus PD630 & Kraft hardwood pulp & 46 & {$[23]$} \\
\hline
\end{tabular}

solvent extraction and either gravimetric assays or chromatographic determination, which are time-consuming multi-step procedures unsuitable for high-throughput analysis and prompt response to changing culture conditions [30]. Moreover, adequate amounts of biomass and, in turn, large sample volumes are required, thus hindering screening and small-scale experiments. To select high-yielding strains, procedures based on lipid extraction are best avoided. At the same time, in situ screening of lipids is not possible with traditional solvent extraction methods, as cells are not in a viable state. There is a need to develop methods that allow for rapid screening of growth and oil accumulation by various strains and under varied conditions and with reduced sample 
amounts [31, 32]. To this end, several alternative techniques enabling high-throughput and reliable lipid quantification have emerged recently [31, 33]. Fluorescence spectroscopy is considered the simplest and most cost-effective alternative to gravimetric methods for lipid quantification, and fluorescence detection methods have been developed for direct lipid measurements [34-36]. Fluorescent dyes such as Nile Red and boron-dipyrromethene (BODIPY) 505/515, which interact with intracellular lipids and emit fluorescence signals correlated to lipid content, are commonly used in such assays [31, 37]. These methods, based on a vital dye, offer a rapid and inexpensive approach for measuring lipid content and can be applied in various systems, in situ and in vitro [35]. Other non-destructive methods, such as infrared (IR), nuclear magnetic resonance (NMR), and Raman spectroscopy, have also been used to some extent for lipid determination in oleaginous microorganisms [38-42]. Techniques for lipid content determination in microalgae have been thoroughly described in several recent reviews [31, 33-35] and are also commonly applied to lipid quantification in other oleaginous microorganisms. Other important factors, such as the degree of unsaturation and saturation, the position and number of double bonds in the hydrocarbon chain, the amount of free fatty acids, TAGs, diacylglycerols
(DAGs), monoacylglycerols (MAGs), and steryl esters, should also be taken into consideration when evaluating microbial lipids for biofuels [43]. Consequently, it is important to assess both TAG content and chemical composition of microbial lipids.

The aim of this review is to summarize some of the important aspects of conventional methods for total lipid analysis, including compositional analysis, and novel techniques that can be used for lipid detection and quantification (see Fig. 1).

\section{Conventional lipid quantification}

Conventional lipid quantification methods in oleaginous microorganisms include gravimetric assays, transesterification, and chromatography coupled with spectroscopy. Gravimetric methods for total lipid quantification encompass a series of events including harvesting of microbial biomass, drying, disruption of cellular integrity, and extraction of lipids. With this method, it is only possible to estimate the total amount of lipids, but not their composition. Hence, traditionally, the compositional analysis of lipids has been performed by chromatographic techniques such as gas chromatography (GC) coupled with an appropriate detector, following lipid derivatization into their esterified form $[44,45]$.

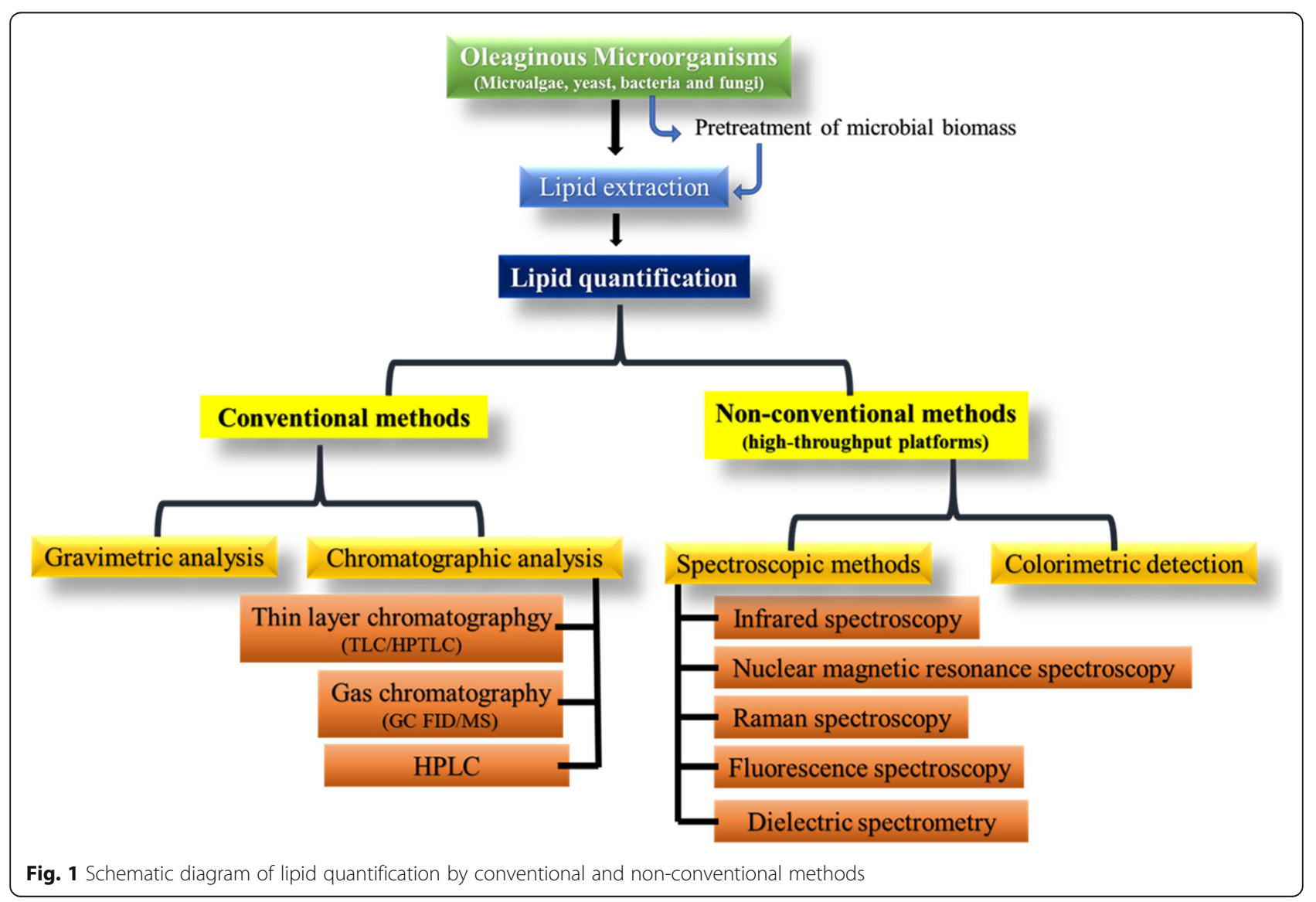




\section{Gravimetric analysis}

Gravimetric determination of total lipid content is the most widely used method for quantifying microbial lipids. In this method, lipids are extracted from microbial cells by one of the techniques listed in Table 2 .

Because lipids can be polar (phospholipids) or nonpolar (TAGs), their partitioning must be done according to differences in their polarity $[64,65]$. In general, lipid extraction from oleaginous microorganisms can be performed through two different routes, the dry and wet route. The latter is advantageous over the former as it is more cost-effective and less energy-intensive because it eliminates the drying step prior to extraction [66, 67]. Bligh \& Dyer and Folch are the oldest and most commonly used lab-scale methods for lipid extraction, whereby a 2:1 mixture of chloroform and methanol is used as solvent $[46,68,69]$ and total lipids weight is determined gravimetrically after solvent evaporation. Various micro- and macro-gravimetric methods have been proposed. In macro-gravimetric methods, samples ranging from 0.5 to $5 \mathrm{~g}$ can be processed by the Bligh \& Dyer or Folch techniques; whereas in micro-gravimetric methods, samples up to $100 \mathrm{mg}$ can be processed according to Van Handel's protocol [70].

The extracted lipids are often contaminated with other cellular components, which affects their determination [71] and creates a discrepancy between gravimetric and fatty acid methyl ester (FAME) analysis. The most common contaminants are pigments such as chlorophyll; however, their interference can be eliminated by measuring the concentration of pigments by fluorometry [72] Gravimetric methods for lipid quantification are applied on a routine scale as no special equipment or training are required and they are relatively fast. However, they require careful optimization and cannot provide information about lipid classes so, in the end, results have to be verified by other means such as GC [73].

\section{Chromatographic techniques}

The most common chromatographic methods for lipid analysis are thin-layer chromatography (TLC), GC, and high-performance liquid chromatography (HPLC), used alone or in conjugation with mass spectrometry (MS), tandem quadrupoles (MS/MS), flame ionization detector (FID), and time-of-flight (TOF).

\section{Thin-layer chromatography}

TLC is a valuable analytical tool for the qualitative and quantitative analysis of lipids that can rapidly resolve lipid components such as TAGs, DAGs, MAGs, and cholesterol esters in a single step without altering their chemical properties [74, 75]. The availability of commercial pre-coated chromotoplates has greatly improved the reproducibility of lipid separation over hand-made TLC plates. Moreover, lipid separation by TLC or its high-performance (HPTLC) variant, has benefitted substantially from the availability of good-quality absorbent materials, including high-performing silica bonded phases and impregnated layers [76]. Qualitative analysis can be performed on the basis of lipid components and their reactions with various types of reagents; e.g., acidic ferric chloride is used to detect cholesterol and cholesteryl esters, which appear as red to violet spots [77]. Some

Table 2 Overview of important extraction methods and their efficiency for lipid recovery

\begin{tabular}{|c|c|c|c|c|c|}
\hline Method & Efficiency & Cost & Energy demands & $\begin{array}{l}\text { Industrial } \\
\text { perspective }\end{array}$ & References \\
\hline $\begin{array}{l}\text { Conventional solvents } \\
\text { such as chloroform/ } \\
\text { methanol, hexane, } \\
\text { or ether }\end{array}$ & $\begin{array}{l}\text { Depends on the species of } \\
\text { microorganism, pretreatment } \\
\text { of biomass, moisture content, } \\
\text { type of solvent, solvent: } \\
\text { biomass ratio, treatment time, etc. }\end{array}$ & $\begin{array}{l}\text { Mainly the cost of solvents } \\
\text { and reactors, possible reuse } \\
\text { of solvents, energy-intensive } \\
\text { process }\end{array}$ & $\begin{array}{l}\text { Drying of cellular biomass, } \\
\text { heating of solvent, } \\
\text { distillation of solvent }\end{array}$ & $\begin{array}{l}\text { There are } \\
\text { reports at a } \\
\text { larger scale }\end{array}$ & {$[46]$} \\
\hline Super critical $\mathrm{CO}_{2}$ & $\begin{array}{l}\text { Varies with flow rate of } \mathrm{CO}_{2} \\
\text { pressure, and exposure time }\end{array}$ & $\begin{array}{l}\text { Mainly the cost of equipment } \\
\text { and its maintenance }\end{array}$ & $\begin{array}{l}\text { Distillation/heating of } \\
\text { solvents if paired with } \\
\text { co-solvent, maintaining } \\
\text { high-pressure conditions }\end{array}$ & $\begin{array}{l}\text { No report at } \\
\text { an industrial } \\
\text { scale }\end{array}$ & {$[47-51]$} \\
\hline Liquid $\mathrm{CO}_{2}$ & $\begin{array}{l}\text { Requires cell disruption to achieve } \\
\text { better yield, usually lipid yield } \\
\text { is low }\end{array}$ & $\begin{array}{l}\text { Maintenance of high-pressure } \\
\text { conditions ( } 15 \mathrm{MPa}) \text {, cell } \\
\text { disruption }\end{array}$ & $\begin{array}{l}\text { Distillation/heating of } \\
\text { solvents if paired with } \\
\text { co-solvent }\end{array}$ & $\begin{array}{l}\text { No reports } \\
\text { at a larger } \\
\text { scale }\end{array}$ & {$[52,53]$} \\
\hline $\begin{array}{l}\text { Microwave-assisted lipid } \\
\text { extraction }\end{array}$ & $\begin{array}{l}\text { Simple, rapid process, effective } \\
\text { for robust species, easy to scale up; } \\
\text { does not require dewatering of } \\
\text { microorganisms; highly efficient at } \\
\text { lab scale }\end{array}$ & $\begin{array}{l}\text { Low operating costs but high } \\
\text { maintenance costs of } \\
\text { equipment }\end{array}$ & $\begin{array}{l}\text { High energy consumption, } \\
\text { recovery of thermolabile } \\
\text { compounds may require } \\
\text { cooling }\end{array}$ & $\begin{array}{l}\text { No reports } \\
\text { at a larger } \\
\text { scale }\end{array}$ & $\begin{array}{l}{[10,46,48,} \\
54-56]\end{array}$ \\
\hline $\begin{array}{l}\text { Ultrasonication-assisted } \\
\text { lipid extraction }\end{array}$ & $\begin{array}{l}\text { Short extraction time, simple to } \\
\text { operate, highly reproducible results, } \\
\text { energy-effective in small volume, } \\
\text { cell wall hinders lipid recovery }\end{array}$ & Mainly cost of equipment & $\begin{array}{l}\text { Large volume of sample, } \\
\text { requires high energy }\end{array}$ & $\begin{array}{l}\text { Not suitable } \\
\text { for } \\
\text { large-scale }\end{array}$ & {$[46,56-63]$} \\
\hline
\end{tabular}


examples of lipid classes and their staining reagents are mentioned in Table 3 [78]. Quantitative lipid analysis by TLC can be done by either recovering the desired lipid component from the chromatoplate and analyzing it by established analytical tools, or through its direct analysis on the chromatoplate [75]. Quantitative analysis of lipid classes by TLC was performed after lipid extraction from oleaginous microalgae such as Nannochloropsis oculata and Dunaliella salina [58], as well as from oleaginous yeasts such as Yarrowia lipolytica and Cryptococcus curvatus $[79,80]$.

For the separation of TAGs, DAGs, MAGs, and cholesterol esters, a mobile phase of hexane:diethyl ether:acetic acid $(85: 15: 1, v / \mathrm{v} / \mathrm{v})$ is often used and the spots are typically visualized by staining with a methanolic $\mathrm{MnCl}_{2}$ solution, followed by charring of the plate at $120^{\circ} \mathrm{C}$ [74]. Different TAGs can be separated by TLC based on their molecular weight $[81,82]$. Using a mixture of petroleum ether and diethyl ether, long-chain TAGs can be eluted first, followed by short-chain TAGs [82]. Normal-phase TLC containing silicic acid is often used to separate TAGs with varied degrees of saturated and unsaturated fatty acids [83]. TAGs molecular species can also be resolved by argentation TLC $\left(\mathrm{Ag}^{+} \mathrm{TLC}\right)$ or reverse-phase TLC [83].

Low costs for quick analysis of small samples, ease of handling, and reproducibility of results are the main advantages of TLC [78]. The main disadvantages are limitations of preparative applications for TLC/HPTLC and lipid oxidation (mainly unsaturated fatty acids) during exposure to atmospheric oxygen [78].

\section{Gas and liquid chromatography coupled to mass spectrometry} Liquid chromatography (LC, HPLC, and ultra-high-performance liquid chromatography) and GC have been widely employed for lipid profiling and are usually coupled with MS for a more detailed analysis [84]. Other detectors coupled to GC for lipid profiling are the MS/MS, FID, and TOF MS; whereas HPLC can be coupled to an evaporative light scattering detector (ELSD). Among the different ionization techniques for MS, fast atom bombardment (FABMS) [85], electrospray ionization (ESI), matrix- assisted laser desorption and ionization (MALDI) [86], and paper spray ionization [87] have been applied for lipid analysis from oleaginous microorganisms.

Various conventional chromatographic/spectrometric methods for lipid quantification and profiling of oleaginous microorganisms are presented in Table 4. The most commonly applied steps before LC or GC are cell lysis and lipid extraction, as well as the conversion of saponifiable lipids directly into acyl esters of fatty acids via a transesterification reaction [33]. The reaction includes the addition of an acid or base as catalyst and an alcohol, most often methanol [99]. An alternative to the conventional process is direct or in situ transesterification, whereby lipid extraction and transesterification are performed in a single step. Factors critical for the efficiency of direct transesterification include alcohol type and alcohol:lipid ratio, cells' water content, reaction conditions (i.e., temperature and time), use of co-solvents, and role of the catalyst. For instance, catalyst-free supercritical processes using methanol have been applied for biodiesel production [100]. Therefore, the meticulous design of the transesterification step is critical for an adequate quantification of lipids by subsequent chromatographic methods.

GC/MS or LC/MS have excellent sensitivity, molecular specificity, and precision, and represent the current 'gold standard' for the quantification of microalgal cellular composition [101]. However, sample pretreatment makes these methods destructive, time-consuming, environmentally unfriendly, and does not allow for real-time lipid content monitoring. GC and/or MS have been employed successfully in oleaginous microorganisms for biodiesel production, such as the analysis of metabolic flux distribution in Chlorella protothecoides [102] and the automated biochemical analysis of aquatic microorganisms [103].

Thermal pyrolysis of biological macromolecules generates volatile compounds that can be detected by GC-MS/ MS and characterized both quantitatively and qualitatively. Pyrolysis GC/MS was applied for the biochemical determination of proteins, carbohydrates, and lipids from 26 microalgae and cyanobacteria [91]. Its advantages include minimal sample preparation, reduced analysis time, and low amount of sample. Barupal et al. (2010) combined

Table 3 Qualitative estimation of lipid classes by specific reagents following separation by TLC [78]

\begin{tabular}{lll}
\hline Lipid class & Reagent & Results \\
\hline Free fatty acids & 2',7'-Dichlorofluorescein/ AlCl3/FeCl3 & Appears as rose color after few minutes \\
Glycolipids & a-Naphthol/sulfuric acid & Yellow spots \\
& Orcinol/sulfuric acid & Blue-purple spots \\
& 5-Hydroxy-1-tetralone in 80\% sulfuric acid & Glycolipids give yellow spots easily distinguishable \\
& from the light blue spots of phospholipids
\end{tabular}




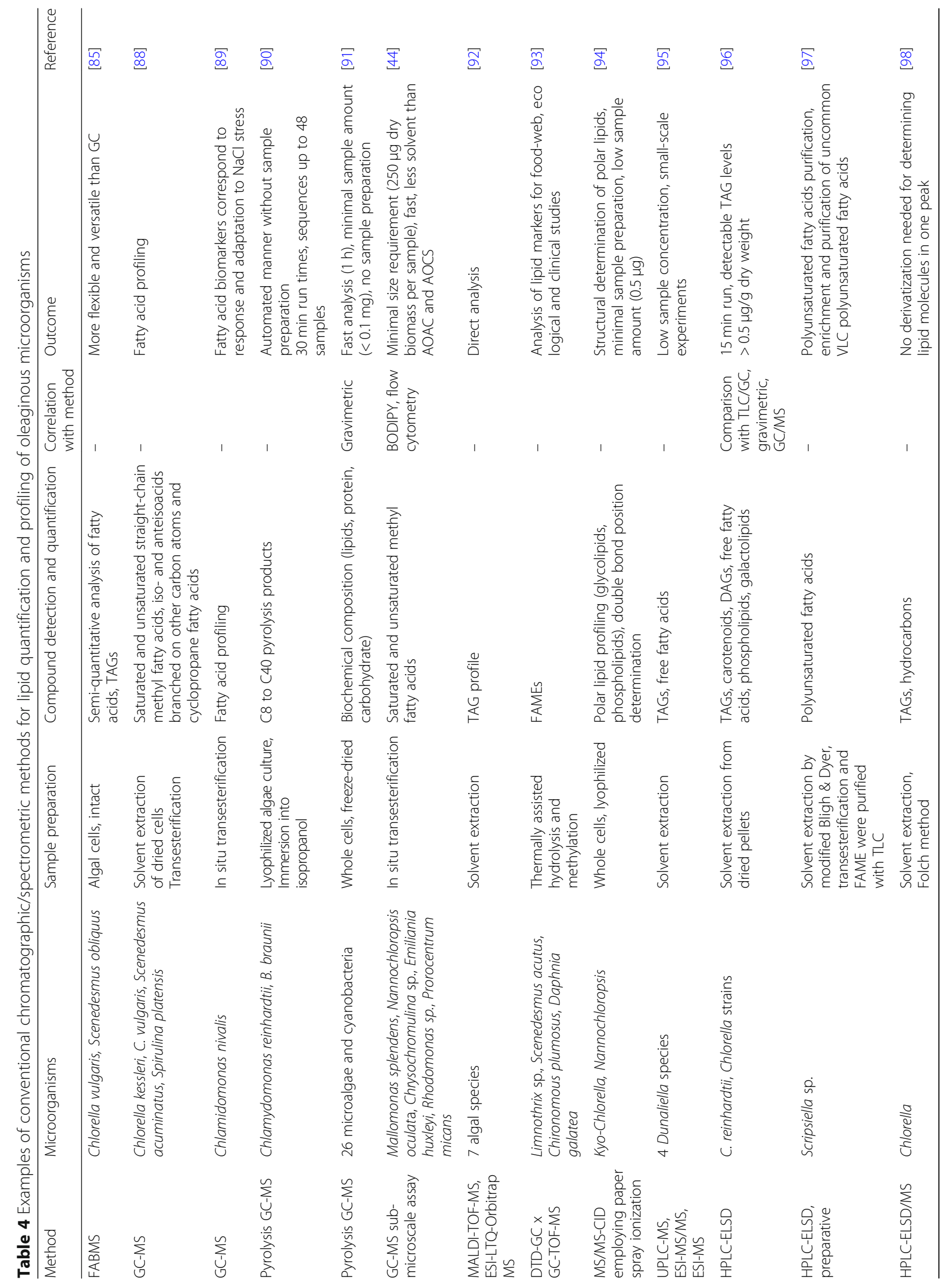


pyrolysis GC/MS with existing computational tools to perform a phenotypic analysis of the model organism Chlamydomonas reinhardtii and the lipid-rich Botryococcus braunii based on their hydrocarbon content. The method yielded a clear profile of pyrolysis products with a carbon-chain length of C8 to C40 [90].

A rapid, microscale, single-step in situ protocol for $\mathrm{GC} /$ MS lipid analysis, requiring only $250 \mu \mathrm{g}$ dry mass per sample, was developed and applied in algae and aquatic organisms, combined with fluorescent techniques (BODIPY 505/515) and flow cytometry [44]. The assay included FAME preparation of lyophilized cells by exposing them to $\mathrm{BF}_{3}$ in methanol, heating at $100{ }^{\circ} \mathrm{C}$ for $1 \mathrm{~h}$, a two-step phase separation, and subsequent analysis. The in situ extraction required significantly less solvent and reagent (five to twenty times) than other conventional extraction methods, while a full profile of saturated and unsaturated fatty acids was obtained, thus monitoring the timing of fatty acid synthesis in different algal species.

MALDI-TOF MS is a fast and sensitive method applied in lipid research for apolar and polar lipids [86]. MALDI-TOF MS was used for the compositional analysis of intact, non-derivatized TAGs extracted from marine microalgae, along with ESI-LTQ-Orbitrap MS [92]. Further, direct thermal desorption $\mathrm{GC} / \mathrm{GC} /$ TOF-MS has been applied for fatty acid detection in microalgae and aquatic meiofauna [93].

Ambient ionization MS analyzes samples by forming ions outside the mass spectrometer, thus avoiding the chemical separation of extracts, which in turn reduces analysis time and the need for solvents [104]. Paper spray ionization is a relatively new method that requires loading of the sample onto a triangular piece of chromatographic paper, the addition of solvent, and application of high voltage that creates ions for MS analysis [87]. MS/MS using paper spray ionization was employed for direct characterization of polar lipids in whole cells of two green microalgae species [94].

In spite of HPLC being coupled mostly with ultraviolet (UV)-visible or MS detectors, ELSD has been proposed to be more accurate for lipid quantification than UV-visible detectors, and less costly and easier to use than MS. Furthermore, ELSD allows the simultaneous quantification of not only TAGs, but also other neutral lipids that are of interest for biofuel or biodiesel production, which is not possible with MS. HPLC-ELSD has been used for the purification of methyl C16-C28 polyunsaturated fatty acids in Scrippsiella sp. [97]. Direct analysis of extracted lipids from Chlorella employing HPLC-ELSD-MS gave quantitative information on all lipid classes while reducing information and material losses associated with purification or derivatization steps required for GC analysis [98].

\section{Non-conventional quantification of lipids, including high-throughput platforms}

As previously stated, rapid and inexpensive methods for estimating lipid content in oleaginous microorganisms are required to screen numerous candidate strains and identify optimal cultivation conditions. To this end, various systems enabling the processing of large numbers of strains in a reasonable time are being developed and are discussed below.

\section{Spectroscopic methods \\ Infrared spectroscopy}

IR spectroscopy has gained ground as a fast and non-invasive lipid quantification method that can be applied on small amounts of whole cells for real-time monitoring and screening of cultures [40, 105]. Flow-cytometry and Fourier transform infrared spectroscopy (FTIR) supported by multivariate analysis, have been proposed as fast and reliable means to monitor and quantify lipids over time in the oleaginous yeasts Cryptococcus curvatus, Rhodosporidium toruloides, and Lipomyces starkeyi [38, 40]. Microtiter plate cultivation systems combined with FTIR have also been used as a high-throughput online platform for screening of oleaginous filamentous fungi [106] and to evaluate the efficiency of lipid extraction processes in oleaginous fungi [107]. FTIR analysis of various microorganisms and their sample preparation are presented in Table 5.

FTIR has been applied since 2000 to detect macromolecules in microalgae [112]. For example, Giordano et al. (2001) studied the carbon allocation pattern in Chaetoceros muelleri L. under nitrogen-limited conditions [112]. They suggested that, under such conditions, carbon was directed towards lipid rather than protein and chlorophyll synthesis, irrespective of the source of nitrogen [112]. A similar study by Herad et al. (2005) using synchrotron IR micro-spectroscopy examined the distribution of lipids and proteins in the microalgae Micrasterias hardyi when the supply of phosphorus and nitrogen was restored [113]. Sigee et al. (2007) studied carbon allocation during phosphorus limitation in Scenedesmus subspicatus using synchrotron-based FTIR micro-spectroscopy and suggested that lipid accumulation in this microalgae was more pronounced under cellular phosphorus limitation than extracellular phosphorus starvation [114]. FTIR micro-spectroscopy was used also by other authors to investigate the allocation of carbon towards lipids in various microalgal species $[108,115,116]$. Although these studies were based on a shifting ratio of macromolecules inside the cells, the exact quantification of lipids inside the cellular matrix by FTIR could not be achieved until a chemometric correlation was proposed by Laurens and Wolfrum [117]. These authors developed a multivariate calibration method that enabled the quantitative analysis of 


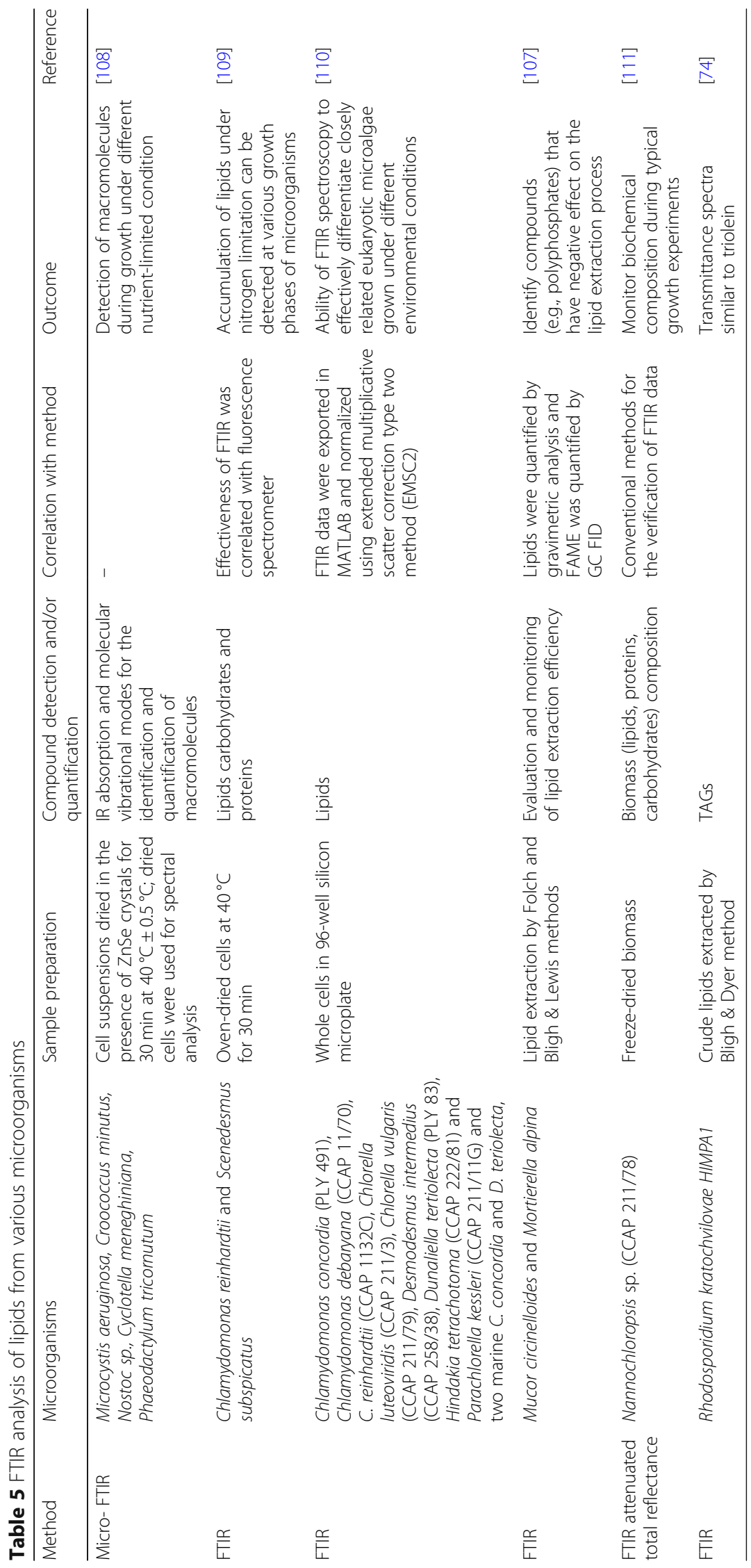


exogenous spiked neutral (trilaurin as a TAG) and polar lipids (phosphatidylcholine as phospholipid) in four different microalgae on the basis of near-infrared (NIR) and FTIR spectroscopy [117]. However, the correlation between the amount of phosphatidylcholine and FTIR signal was sometimes problematic, which might have been due to interference by TAGs whose spectra were similar to that of phosphatidylcholine [118]. Indeed, signal interference remains the major challenge of using FTIR to quantify lipids in microbial cells and the results should be cross-checked with other methods.

\section{Nuclear magnetic resonance spectroscopy}

NMR spectroscopy can be used to determine the composition of complex biological samples. It requires minimal sample preparation and is of low complexity as it does not require chromatographic separation or derivatization of the sample, plus it can be applied to liquid or solid samples (liquid- or solid-state NMR). NMR-active nuclei in lipid molecules include carbon $\left({ }^{13} \mathrm{C}\right)$, hydrogen $\left({ }^{1} \mathrm{H}\right)$, oxygen $\left({ }^{17} \mathrm{O}\right)$, and phosphorus $\left({ }^{31} \mathrm{P}\right)$, with ${ }^{1} \mathrm{H}$ NMR being the most common for lipid profiling of algal samples [119]. ${ }^{1} \mathrm{H}$ NMR allows the quantification of different lipid classes such as steroids and some pigments (carotenoids and chlorophylls), which contain protons with non-overlapping peaks [120]. ${ }^{13} \mathrm{C}$ NMR can be used for the quantification of different lipid components in an extract by way of particular pulse sequences such as inverse gated decoupling and an appropriate standard [120]. An advantage of NMR is that it provides detailed structure-specific information, while the risk of chemical alterations such as oxidation is kept minimal [120]. Other advantages include the high speed of analysis compared to traditional techniques (i.e., GC, MS, UV or IR spectroscopy) and that it is non-destructive, enabling recovery of the sample for further analysis.

${ }^{1} \mathrm{H}$ and ${ }^{13} \mathrm{C}$ NMR have been applied for profiling the main components of whole algal cells [39, 119-124]. Besides a complete lipid quantification profile, Sharpal et al. (2015) performed a cost and practicability analysis of the method [121]. While NMR required five-fold less time than GC/MS and a similar operating cost, it was noted that its initial investment was also five times higher. Davey et al. (2012) used a liquid-state ${ }^{1} \mathrm{H}$ NMR with a quantitative method previously developed by Henderson et al. (2012), in which the reference compound was kept in coaxial inserts to avoid interaction with the sample solution. This strategy was applied to quantify TAGs in living microalgae in their growth medium [125]. NMR is ideal for high-throughput calibration of flow cytometry methods aimed at the quantification of cellular TAGs in various algal species [126]. Further, semi-solid NMR techniques, such as high-resolution magic-angle spinning (HR-MAS) and intermolecular multiple-quantum coherence (iMQC), can be used to detect non-TAG lipids [126].

There are several NMR methods and each of them has its advantages and disadvantages. For example, HR-MAS can be used on intact biological samples and results in well-resolved spectra with narrow peaks when the sample is spun at low frequencies at a $54.7^{\circ}$ angle relative to the magnetic field [127]. ${ }^{1} \mathrm{H}$ HR-MAS and ${ }^{13} \mathrm{C}$ NMR have been applied to detect and identify whole algal cells and extracted lipids [125, 128, 129]. A method employing low-field ${ }^{1} \mathrm{H}$ NMR was developed for in vivo online monitoring and real-time tracking of lipid dynamics in C. protothecoides [130].

Time domain (TD) NMR is based on the different relaxation times of hydrogen nuclei in various phases of the analyzed sample [131]. Solids, such as carbohydrates and proteins, show short relaxation times in the order of microseconds, whereas bound water, free water, and lipids have relaxation times in the order of, respectively, a few hundred microseconds, seconds, and a few hundred milliseconds [132]. In TD-NMR, the hydrogen nuclei signal from lipids is separated from that derived from other compounds by applying a spin-echo NMR pulse sequence, and lipid content can be quantified using an appropriate calibration [132]. TD-NMR has already been applied for lipid quantification in heterotrophically grown algae [132]. A drawback of this method is the high amount of sample required (up to 1 gram of lyophilized biomass), and its incapacity to differentiate between neutral lipids (i.e., TAGs) and polar or membrane lipids [125]. Nevertheless, TD-NMR has shown generally good agreement with both lipid extraction and Nile Red staining.

Nuzzo et al. (2013) reported an efficient, fast, and reproducible method for the identification and quantification of different classes of lipids (free fatty acids, TAGs, glycolipids, phospholipids) in microalgae [133]. Their approach used a modified Folch method to extract lipids from cells, followed by direct analysis of the extract with ${ }^{1} \mathrm{H}$ NMR and a reference electronic signal as external standard (ERETIC method) [133]. Accordingly, it was possible to quantify total lipid content, degree of saturation, and class distribution during both high-throughput screening of algal cultures and metabolic analysis during genetic studies. A further simplification of the method was introduced by evaluating sample extracts without partition against water of the chloroform-ethanol phase. The obtained spectra retained the capacity to provide information on TAGs, free fatty acids, unsaturated, and saturated fatty acids, making this simplified method suitable for analysis of lipid classes with potential applications in crude oil production or for monitoring biodiesel synthesis. NMR spectroscopy methods applied to various microorganisms for the detection of lipids are presented in Table 6 . 


\section{Raman spectroscopy}

Raman spectroscopy is based on the inelastic scattering of monochromatic light produced by a laser in the visible, NIR or UV range [135]. Raman spectroscopy is a valuable tool for in vivo lipid biomonitoring; however, it can also generate broad spectra for the identification of lipids, proteins, carbohydrates, nucleic acids, and pigments [136]. Different techniques have been developed to boost the Raman signal of target molecules, such as coherent anti-Stokes Raman scattering (CARS), resonant Raman spectroscopy, confocal Raman spectroscopy (CRS), and laser-trapping Raman spectroscopy (LTRS), of which each has its benefits and limitations [119].

Raman spectroscopy is a rapid and non-destructive method for quantifying the degree of lipid unsaturation. The vast majority of chemical composition studies of algal species employs the ratio between $1656 \mathrm{~cm}^{-1}(\mathrm{C}=\mathrm{C})$ and $1445 \mathrm{~cm}^{-1}$ (C-H deformation), often denoted as $\mathrm{I}_{1656} /$ $\mathrm{I}_{1445}$, to determine fatty acid composition. This is done after constructing calibration models based on $\mathrm{C}=\mathrm{C}$ and $\mathrm{CH}_{2}$ coupled with differential calorimetry and melting point data [136]. A general limitation of Raman spectroscopy for lipid detection and quantification is the strong Raman signal of fluorescent pigments and carotenoids, which overlaps with the lipid peaks and interferes with the analysis. This is a major drawback particularly in oleaginous microorganisms with a high photosynthetic signature. To this end, routine Raman signal post-processing includes cosmic noise removal and fluorescence background subtraction, prior to any further spectral analysis.

Traditional Raman spectroscopy is a widely used and simple technique, with strong potential for industrial implementation. However, its application in living systems is limited by the use of significantly higher excitation laser power to produce distinguishable signals, which could lead to photo-damage of specific samples [137], as well as long integration times (100 ms - 1s per pixel) [138]. Stokes Raman spectroscopy was employed to identify carotenoids and TAGs produced by Chlorella sorokiniana and $N$. oleoabundans [139]. However, unexpected variations in fluorescence background levels were observed during prolonged laser exposure, possibly due to photo-bleaching of pigments in chloroplasts and unexplained sudden spikes of high-intensity fluorescence [139]. The lipid content and degree of unsaturation have been determined by NIR-Raman spectroscopy in Chlorella vulgaris [140] and by Raman spectroscopy in B. braunii [138].

CRS is another valuable tool for determining the composition of a single individual cell in vivo, including in algae, as it can provide molecular information by simple, fast, non-invasive, and multiplex measurements [141]. In CRS, the laser light is focused onto a sample through a microscope objective while the backscattered signal is refocused onto a spatial pinhole aperture before returning to the spectrometer, where it is dispersed on a charge-coupled device array to produce a spectrum [135]. CRS generates highly spatially resolved 3D images with little background disturbance [135]. CRS was combined with ordinary least squares analysis to determine the relative composition of different fatty acids in a TAGs mixture from a single cell of Thalassiosira pseudonana. Such approach overcame the limitation of a conventional method based on the $\mathrm{I}_{1656} /$ $\mathrm{I}_{1445}$ ratio, which is not reliable for samples containing three or more different fatty acids [142]. Indeed, CRS identified four major lipid moieties, including myristic, palmitic, palmitoleic, and eicosapentaenoic acid, with high correlation (>0.9) to GC. Although some spectra revealed strong pre-resonant Raman bands of carotenoids, ordinary least squares analysis provided reliable quantitative information. Sharma et al. (2015) benchmarked an integrative approach for lipid biomonitoring via CRS [143]. The method quantified saturated and unsaturated fatty acids $\left(\mathrm{I}_{1650} / \mathrm{I}_{1440}\right)$ and was cross-validated by LC-MS experiments, demonstrating high linear correlation. Recently, a non-destructive and label-free single-cell Raman microspectroscopy method was applied for high spatial resolution monitoring of in vivo spatiotemporal dynamics of lipids and astaxanthin in Haematococcus pluvialis cells induced with $15 \% \mathrm{CO}_{2}$ and high light intensity [141]. Raman micro-spectroscopy has been applied also to quantify the degree of unsaturation by means of the ratiometric method in six species of Mortierella [144]; in situ analysis of lipids accumulated in Botryococcus sudeticus, Chlamydomonas sp., and Trachydiscus minutus [145]; in vivo lipid and carbohydrate quantification of single Chlamydomonas sp. [101]; TAG accumulation in single Nannochloropsis oceanica cells [146]; and quantitative analysis of lipid unsaturation in immobilized Fistulifera solaris [147]. Urban et al. (2011) performed a proof-of-concept study for an integrated and straightforward multidimensional analysis of single Euglena gracilis and C. reinhardtii cells by combining fluorescence and Raman micro-spectroscopy with laser desorption/ionization MS [148].

In CARS, two high-powered laser beams are focused together on a sample generating stronger spectra due to the coherence of the beam. CARS is a non-linear method that provides high 3D sectioning capability for video-rate imaging. Moreover, CARS signals can be easily distinguished from the fluorescent background due to a blue shift of the response signal. New developments in CARS microscopy have removed the primary non-resonant background problem, by employing complex experimental procedures or post-image data processing [149]. The ability to visualize lipids in microalgae by CARS microscopy was demonstrated as proof-of-principle on Coccomyxa subellipsoidea [150]. However, signal overlap between the excited fluorescence of the chlorophyll two-photon and CARS limited the analysis. In subsequent experiments on 


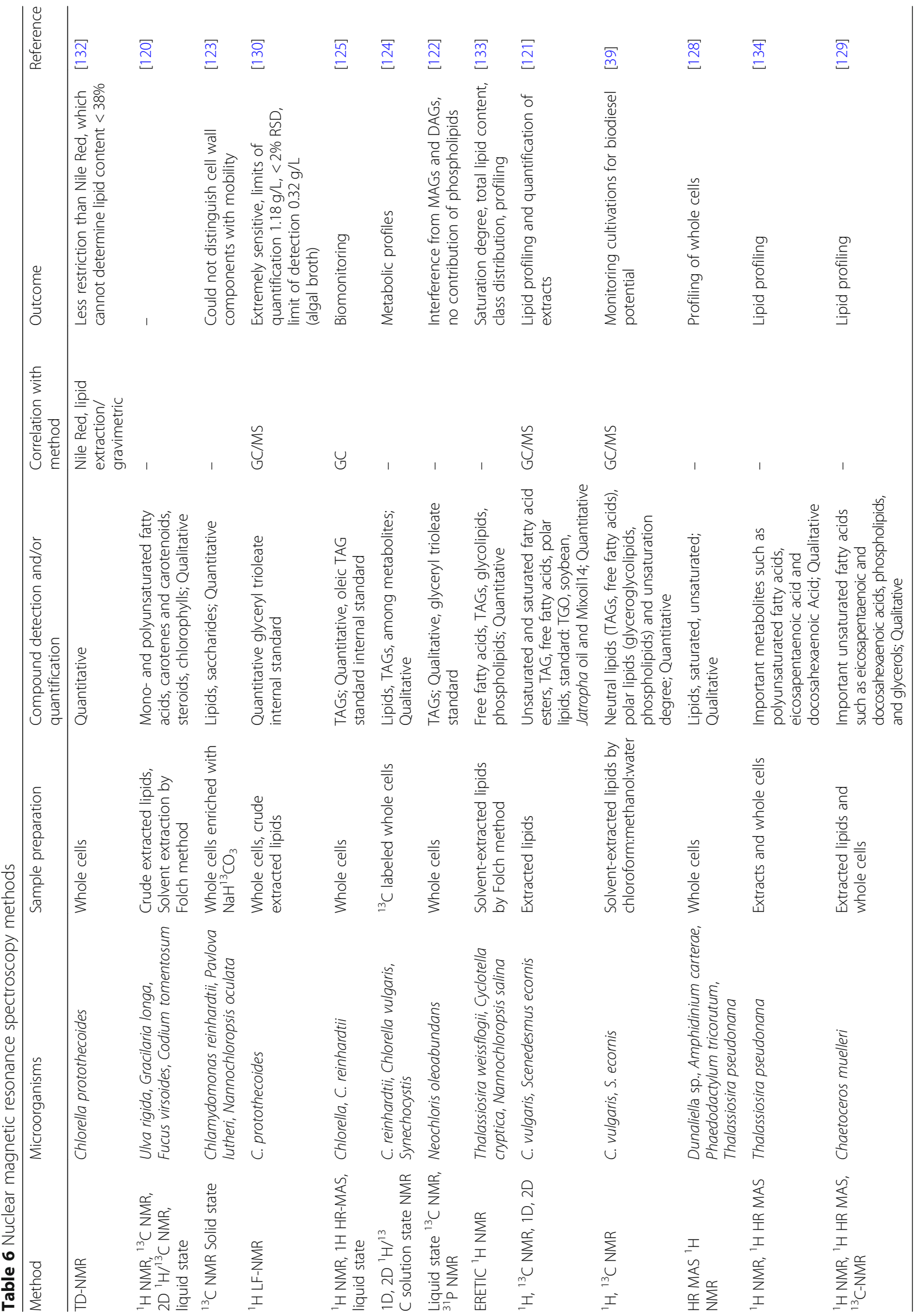


Phaenodactylum tricornutum, the CARS signal and chlorophyll fluorescence were separated by time-gated detection [151]. Jaeger et al. (2016) reported for the first time the direct analysis of lipids in Monoraphidium neglectum by successful separation of the lipid-specific CARS signal and the interfering two-photon excited fluorescence of chlorophyll [152]. Raman spectroscopic methods applied for the quantification of lipids from different microorganisms are presented in Table 7.

Stimulated Raman scattering microscopy has emerged as an alternative to CARS. Unlike CARS, it offers straightforward image interpretation and quantification with improved signal-to-noise ratio. Moreover, it exhibits linear concentration dependence and thus high potential for the quantification of individual molecules in a multicomponent system; its main limitation remains the capacity to probe only a single Raman band at a time. Fu et al. (2012) reported a multiplexing approach that allowed the simultaneous measurement of multiple Raman bands, offering better chemical specificity and quantitative multicomponent analysis [149]. Importantly, they achieved a three-fold higher implementation of multispecies chemical mapping of multispecies than with CRS after in situ or external calibration.

LTRS, a combination of Raman micro-spectroscopy and NIR optical trapping, was introduced for the chemical

Table 7 Raman spectroscopic methods

\begin{tabular}{|c|c|c|c|c|c|c|}
\hline Method & Microorganisms & $\begin{array}{l}\text { Sample } \\
\text { preparation }\end{array}$ & $\begin{array}{l}\text { Compound detection } \\
\text { and quantification }\end{array}$ & $\begin{array}{l}\text { Correlation } \\
\text { with } \\
\text { method }\end{array}$ & $\begin{array}{l}\text { Excitation } \\
\text { wavelegth }(\mathrm{nm}) \text {, } \\
\text { resolution }\left(\mathrm{cm}^{-1}\right)\end{array}$ & Reference \\
\hline Raman micro-spectroscopy & $\begin{array}{l}\text { Haematococcus pluvialis } \\
\text { mutant }\end{array}$ & $\begin{array}{l}\text { Culture cells were } \\
\text { immobilized in } \\
\text { agarose }\end{array}$ & $\begin{array}{l}\text { Total lipids, astaxanthin; } \\
\text { Qualitative }\end{array}$ & - & $532, \mathrm{n} / \mathrm{a}$ & {$[141]$} \\
\hline CRS & Thalassiosira pseudonana & Culture cells & $\begin{array}{l}\text { TAGs, saturated and } \\
\text { unsaturated fatty acids; } \\
\text { Quantitative }\end{array}$ & GC & $785, \mathrm{n} / \mathrm{a}$ & {$[142]$} \\
\hline NIR Raman spectroscopy & Chlorella vulgaris & $\begin{array}{l}\text { Culture cells, fresh } \\
\text { and Iyophilized }\end{array}$ & Total lipids; Quantitative & - & $1064, \mathrm{n} / \mathrm{a}$ & [140] \\
\hline $\begin{array}{l}\text { Raman micro-spectroscopy } \\
\text { integrated with MS }\end{array}$ & $\begin{array}{l}\text { Euglena gracilis, } \\
\text { Chlamydomonas reinhardtii }\end{array}$ & Culture cells & Total lipids; Quantitative & - & $532, \mathrm{n} / \mathrm{a}$ & {$[148]$} \\
\hline $\begin{array}{l}\text { Single-cell Raman } \\
\text { miscro-spectroscopy }\end{array}$ & Fistulifera solaris & $\begin{array}{l}\text { Immobilized cells } \\
\text { on agarose }\end{array}$ & $\begin{array}{l}\text { Unsaturation degree; } \\
\text { Quantitative }\end{array}$ & GC/MS & $532, \mathrm{n} / \mathrm{a}$ & {$[147]$} \\
\hline Single-cell LTRS & $\begin{array}{l}\text { Botryococcus braunii, } \\
\text { Neochloris oleoabundans, } \\
\text { C. reinhardtii }\end{array}$ & Culture cells & $\begin{array}{l}\text { Unsaturation degree; } \\
\text { Quantitative }\end{array}$ & - & $785, \mathrm{n} / \mathrm{a}$ & {$[153]$} \\
\hline CARS & $\begin{array}{l}\text { Phaenodactylum } \\
\text { tricornutum }\end{array}$ & Culture cells & $\begin{array}{l}\text { Lipids and unsaturation } \\
\text { degree; Quantitative }\end{array}$ & GC/MS & $532, \mathrm{n} / \mathrm{a}$ & {$[151]$} \\
\hline Raman micro-spectroscopy & 6 Mortierella species & Culture cells & $\begin{array}{l}\text { Unsaturation degree; } \\
\text { Quantitative }\end{array}$ & GC & 532,8 & {$[144]$} \\
\hline $\begin{array}{l}\text { Multiplex stimulated Raman } \\
\text { scattering microscopy (SRS) }\end{array}$ & B. braunii & Culture cells & $\begin{array}{l}\text { Total lipids, pigments, } \\
\text { proteins; Quantitative }\end{array}$ & - & $\mathrm{n} / \mathrm{a}, 33$ & {$[149]$} \\
\hline $\begin{array}{l}\text { Confocal Raman spectroscopy } \\
\text { and microscopy }\end{array}$ & $\begin{array}{l}\text { Chlorella sorokiniana, } \\
\text { N. oleoabundans }\end{array}$ & Culture cells & $\begin{array}{l}\text { TAGs, carotenoids, } \\
\text { chlorophyll; Qualitative }\end{array}$ & - & $532,2.4$ & {$[139]$} \\
\hline $\begin{array}{l}\text { Single-cell Raman } \\
\text { spectroscopy }\end{array}$ & Chlamydomonas sp. & Culture cells & $\begin{array}{l}\text { Lipid/starch content; } \\
\text { Quantitative }\end{array}$ & GC/MS & 532,6 & {$[101]$} \\
\hline $\begin{array}{l}\text { Single-cell Raman } \\
\text { micro-spectroscopy }\end{array}$ & Nannochloropsis oceanica & Culture cells & TAGs; Quantitative & LC/MS & 532,2 & {$[146]$} \\
\hline Confocal Raman microscopy & C. reinhardtii & Culture cells & $\begin{array}{l}\text { Saturated and } \\
\text { unsaturated fatty } \\
\text { acids; Quantitative }\end{array}$ & LC/MS & 532,3 & {$[143]$} \\
\hline CARS scattering microscopy & Monoraphidium neglectum & Culture cells & $\begin{array}{l}\text { Saturated and unsaturated } \\
\text { fatty acid composition; } \\
\text { Quantitative }\end{array}$ & $\begin{array}{l}\text { GC/MS, } \\
\text { gravimetric }\end{array}$ & $\mathrm{n} / \mathrm{a}$ & {$[152]$} \\
\hline Raman micro-spectroscopy & $\begin{array}{l}\text { Botryococcus sudeticus, } \\
\text { Chlamydomonas sp., } \\
\text { Trachydiscus minutus }\end{array}$ & Culture cells & $\begin{array}{l}\text { Unsaturation degree; } \\
\text { Qualitative }\end{array}$ & GC/MS & $785, \mathrm{n} / \mathrm{a}$ & {$[145]$} \\
\hline Raman spectroscopy & B. braunii & Culture cells & Lipids; Qualitative & - & & {$[138]$} \\
\hline $\begin{array}{l}\text { CARS and spontaneous } \\
\text { Raman spectroscopy }\end{array}$ & Coccomyxa subellipsoidea & Culture cells & Lipids; Qualitative & - & $514, \mathrm{n} / \mathrm{a}$ & {$[150]$} \\
\hline
\end{tabular}


analysis of single living cells in suspension [154]. Laser tweezers allow the immobilization of an individual cell in suspension away from any surfaces, and simultaneous acquisition of a Raman spectrum. Wu et al. (2011) applied LTRS for the analysis of lipid composition in single microalgae cells of B. braunii, $N$. oleoabundans, and C. reinhardtii, along with quantification of the degree of lipid unsaturation using the $\mathrm{I}_{1656} / \mathrm{I}_{1445}$ ratio [146]. LTRS is limited by the weak intensity of the Raman signal compared to fluorescence and interference from the laser-tweezer [146].

\section{Fluorescence spectroscopy}

Many of the high-throughput platforms for measuring neutral lipids produced by oleaginous microorganisms are based on fluorescence detection. These tools commonly employ small-molecule dyes, such as BODIPY 505/515 and Nile Red, for in situ screening. The dyes have their respective advantages and disadvantages in terms of photo/ chemical stability, optical properties, and solubility. Moreover, their applicability is highly species- and strain-specific, so the method has to be tailored accordingly to ensure that fluorescence values can be properly correlated to lipid content $[34,155]$. Intracellular lipid content determination requires the dye to be dissolved in a solvent carrier, adding the solution to the harvested cells, staining in a dark room at optimal temperature, centrifugation and washing of the cells, resuspension, and spectrometric analysis. For quantitative measurements, calibration curves correlating lipid concentration with emission intensity can be easily prepared.

Nile Red (9-diethylamino-5H-benzo[ $\alpha]$ phenoxazine-5-one) is a relatively photostable lipophilic fluorescent dye that was first used by Cooksey et al. (1987) in microalgae [37]. Nile Red has some limitations, such as spectral interference with the autofluorescence of chlorophyll, non-specific fluorescence, and inconsistent cell uptake. The latter is exacerbated in algal species with thick cell walls. This complicates the development of consistent fluorescence protocols, while dye uptake is dependent on cell viability [126]. Further, Nile Red is intensely fluorescent in organic solvents, but has a low quantum yield in water [156]. Due to susceptibility of its chromophore to changes in solvent polarity and dielectric constant, this dye fluoresces at defined wavelengths depending on solvent polarity [157]. Emission wavelengths vary with the hydrophobicity degree of lipids and a blue shift of emission maxima is observed with decreased solvent polarity. Hence, by choosing proper excitation and emission wavelengths, it is possible to use more hydrophobic conditions to obtain correct neutral lipid measurements and distinguish them from polar lipids [156]. Interaction of Nile Red with neutral lipids results in shorter emission wavelengths $(<590 \mathrm{~nm})$ than with polar lipids $(>590 \mathrm{~nm}$ ), enabling differentiation between them [140].
The main factors affecting Nile Red fluorescence, uptake, and intensity have been established. The permeability of cell walls can be improved by using stain carriers, such as dimethyl sulfoxide (DMSO; 4-25\% v/v), glycerol $(0.1-0.125 \mathrm{mg} / \mathrm{mL})$ or ethylenediaminetetraacetic acid (EDTA; $3.0-3.8 \mathrm{mg} / \mathrm{mL}$ ). Temperatures ranging from 30 to $40^{\circ} \mathrm{C}$ have also been shown to facilitate Nile Red diffusion across the cell wall. The interaction between Nile Red and lipids can be further improved by using a low dye:cell ratio $(0.25-2.0 \mu \mathrm{g}$ dye $/ \mathrm{mL})$ and cell concentrations $>5 \times$ $10^{4}$ cells $/ \mathrm{mL}$. Finally, to determine the maximum Nile Red fluorescence intensity, it is recommended to scan excitation and emission for up to $40 \mathrm{~min}$ [35].

Several Nile Red-based methods have been developed recently for rapid screening of lipid production in algal, yeast and fungal strains [156, 158-160]. Chen et al. (2011a) proposed a high-throughput multi-well microplate-based method with low sample requirements that allows for rapid analysis of multiple samples simultaneously. Unfortunately, lack of reproducibility of fluorescence measurements together with a non-linear response between intensity and oil content has limited the use of this method [159]. In an attempt to address measurement variability and to avoid using a calibration standard, Bertozzini et al. (2011) suggested the use of known amounts of internal standard (triolein) in combination with Nile Red staining [161]. However, this method is not applicable to algal species with thick cell walls that restrict the uptake of Nile Red. Furthermore, differences in relative Nile Red fluorescence by various lipid classes and the different distribution between dye and triolein globules, may result in under- or overestimation of cell lipid content. Sitepu et al. (2012) developed an improved high-throughput assay using DMSO but eliminated the washing step, reduced the Nile Red concentration, and proposed kinetic readings rather than a single time point [162]. Several cell treatment approaches have been tested aiming to increase the permeability of Nile Red; these include microwaves [159], ultrasonic treatment [163], EDTA [164], and mild cell pre-bleaching [165].

An alternative to Nile Red is the dye BODIPY 505/515 (4,4-difluoro-1,3,5,7-tetramethyl-4-bora-3a,4a-diaza-s-indacene), a highly lipophilic green fluorophore. BODIPY $505 / 515$ can stain a variety of algae irrespective of cell wall properties [166]. Compared to Nile Red, it has higher fluorescent quantum yield and a narrower emission spectrum, higher sensitivity, and better reproducibility [167]. BODIPY 505/515 has been the fluorescent marker of choice for the evaluation of intracellular lipids in algae [166, 168]. TAG content in BODIPY 505/ 515-stained $C$. vulgaris by single-cell fluorescence strongly correlated with the result obtained by ${ }^{1} \mathrm{H}$ NMR [126]. BODIPY 505/515 dissolved in DMSO at a final concentration of $1-10 \mu \mathrm{M}$ was shown to selectively stain 
lipid bodies of several taxa of live algae. Moreover, the concentration of DMSO itself was only in the range of $0.02-0.2 \%$, much less than $20-30 \%$ for Nile Red [166, 169]. Another advantage of BODIPY 505/515 is that it selectively binds to lipid bodies, whereas Nile Red binds also to other cellular compartments [166]. As BODIPY 505/ 515 has a higher oil-to-water partition coefficient than Nile Red, it can bind more specifically to neutral lipids [168]. Further, with an excitation wavelength of $488 \mathrm{~nm}$ and an emission maximum at $515 \mathrm{~nm}$, its emission spectrum is distinct from that of chloroplasts $[166,169]$. Disadvantages of BODIPY 505/515 include medium background fluorescence, overlap with chlorophyll, and dye-dye interactions that lead to variability during measurements [166]. The ideal incubation temperature for BODIPY $505 / 515$ staining is $25^{\circ} \mathrm{C}$ and the optimal biomass concentration is $10^{6}$ cells $/ \mathrm{mL}$ for $1.12 \mu \mathrm{g} / \mathrm{mL}$ of dye [169]. BODIPY 505/515 has also been shown to stain oil-containing organelles within minutes and maintain fluorescence efficacy over at least 20-30 min, being more photostable than Nile Red $[166,168,169]$.

Both dyes have been compared for their accuracy; however, their applicability depends on the experimental conditions and microorganism species. For example, both were evaluated in situ in a microbioreactor system to monitor real-time production of intracellular lipids in the yeast $Y$. lipolytica. While online detection of BODIPY 505/515 revealed a linear correlation between fluorescence and intracellular lipid concentration, no fluorescence was observed when Nile Red was used. This could be explained by the reduced photostability of Nile Red [170]. In contrast, BODIPY 505/515 was found unsuitable in a Nile Red staining protocol for various microalgae species that used a microplate fluorescence reader [171].

Recently, the blue fluorescent neutral lipid-specific dye AC-202 was evaluated as an alternative for labelling lipid droplets in the model green alga $C$. reinhartii and the model diatom P. tricornutum [172]. AC-202 belongs to a class of dyes that are analogs of thalidomide (2,6-diisopropyl phenyl-4/5-amino-substituted-4/5,6,7-trifluorophthalimides) and show very low toxicity to plant cells. It can reveal subtle intracellular modifications in neutral lipid content, either alone or in combination with Nile Red or BODIPY 505/ 515. Moreover, owing to its elevated lipid specificity, high sensitivity, and low background signal, it could identify metabolic and signalling pathways implicated in lipid formation, greatly surpassing the results obtained by Nile Red and BODIPY 505/515 [172].

Droplet-based microfluidic methods have been recently developed for high-throughput analysis and screening of lipid content in algal cultures. Such systems are based on the formation of aqueous droplets in an immiscible fluid (carrier oil) that are capable of encapsulating one or more cells, so they can be processed and analyzed in parallel within a short period. Moreover, in combination with fluorescence staining, they have been proven useful to analyze oil accumulation in a high-throughput manner in different species and in single cells [173]. A digital microfluidic system for high-throughput screening of growth and lipid production in Cyclotella cryptica, evaluating hundreds of culture conditions has been demonstrated [171]. In another study, alginate hydrogel microcapsules containing BODIPY 505/515-stained single cells were used to analyze the in situ lipid content of individual $C$. vulgaris, Chlamydomonas sp., and B. braunii algae [174].

Flow cytometry allows to simultaneously measure fluorescence and sort individual stained cells, resulting in the selection and isolation of target populations [171]. Staining with either Nile Red or BODIPY 505/515 has been applied for in vivo flow cytometry quantification of lipids in individual microalgae [36, 166, 167]. Fluorescence-activated cell sorting (FACS) has been applied for the high-throughput sorting of algal cells with high lipid accumulation such as hyperaccumulating mutants of $C$. reinhardtii [175]. Terashima et al. (2015) proposed the Chlamydomonas high-lipid sorting (CHiLiS) strategy for isolating viable high-lipid cells from a pool of 60,000 mutants stained by Nile Red [176]. An advantage of FACS is that the cell sorter takes into account the fluorescence of each cell individually rather than bulk fluorescence measurements. Moreover, by vitally staining with Nile Red or BODIPY 505/515, processed cells can be seeded to produce new algal lineages with desired characteristics such as lipid hyperaccumulation [166]. For example, Nannochloropsis strains have been vitally stained with Nile Red for high-throughput screening and flow cytometric cell sorting, to obtain pure high-lipid producing cultures [160]. In this case, glycerol was used instead of DMSO as a carrier solvent because it did not inhibit cell growth.

Furthermore, high-content image analysis methods have been developed for the screening of oleaginous yeasts [177]. Specifically, lipid droplet accumulation was analyzed by the acquisition of high-quality confocal images of Nile Red-stained cells. The ensuing morphological information enabled a detailed study of lipid droplet dynamics on a single-cell scale. Davis et al. (2014) applied hyperspectral confocal fluorescence spectroscopy for the in vivo localization of lipid bodies in four microalgae and to quantify lipid yield at a single-cell level [178]. Various lipophilic fluorescence dyes used in fluorescence spectroscopic analysis of lipids from different microorganisms are presented in Table 8.

\section{Dielectric spectrometry}

Dielectric methods are based on the different permittivity and conductivity of cell components and measure the dielectric properties of a medium as a function of 


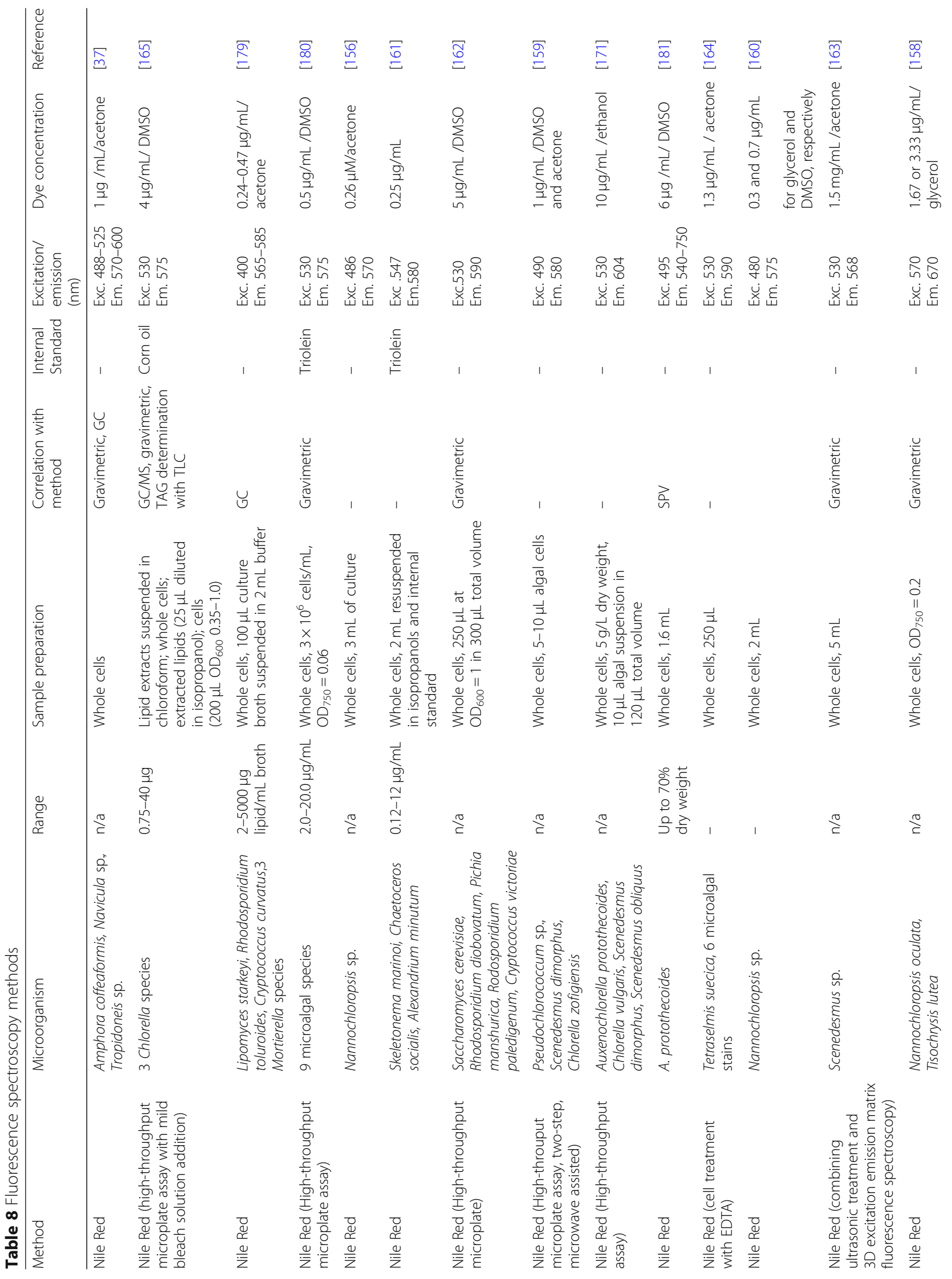




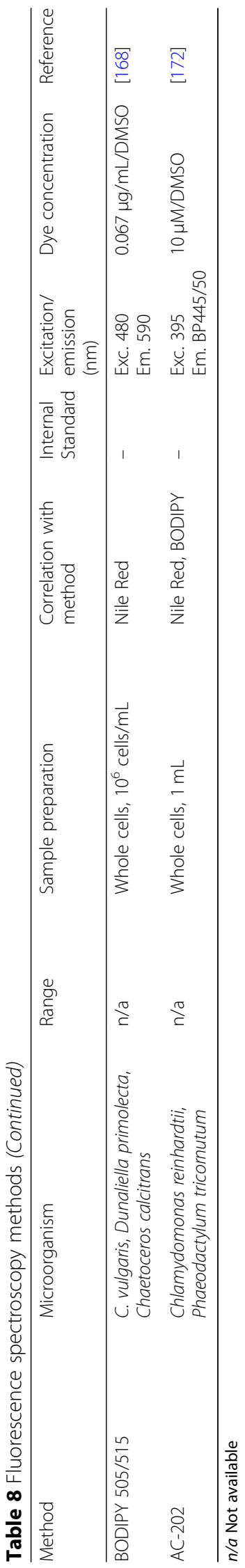


frequency. They provide a rapid, non-invasive, and label-free method for determining the composition of lipids in a cell, as the critical frequency is sensitive to cellular lipid content but is not affected by changes in cell concentration [182]. Dielectric spectra have been shown to correlate with the oil content in Mortierella alpina cells [183], whereas different C. protothecoides electrorotation spectra have been correlated with changes in lipid content [184]. Accordingly, dielectrophoresis was applied for the binary separation of Chlorella cells with different lipid contents, suggesting that lipid accumulation influenced the dielectric properties of algal cells [185]. Cells from the model alga $C$. reinhardtii have been dielectrically characterized and correlated with variations in lipid content induced by nitrogen starvation [186]. The application of dielectric spectrometry requires simple instrumentation such as a vector network analyzer and minimal sample preparation as cells are centrifuged and resuspended in fresh medium. Automated single-cell dielectric characterization methods for online lipid measurements could be used for the biomonitoring of industrial biodiesel production.

\section{Other methods}

A simple and sensitive spectrophotometric method was developed for the quantification of fatty acids derived from microalgal cultures of $N$. oculata and D. salina [187]. The procedure includes cell lysis, followed by lipid saponification, fatty acid extraction, and formation of copper-fatty acid complexes after reaction with triethanolamine-copper salts. The organic phase was detected by measuring absorbance at $260 \mathrm{~nm}$. The developed method was reproducible and provided quantification of nanomoles of lipids using only $1 \mathrm{~mL}$ of culture. However, it is a multi-step method, which requires the use of solvents for cell lysis, saponification, and extraction of fatty acids.

\section{Colorimetric detection}

Colorimetric methods for lipid quantification constitute an attractive choice due to their fast response and simplified sample handling; however, they also usually require other preliminary steps such as cell disruption and lipid extraction. The sulfo-phospho-vanillin (SPV) method that was initially developed by Charbol and Charonnat (1937) for the quantification of serum total lipids is the most commonly used colorimetric technique for lipid quantification in oleaginous microorganisms [188]. The SPV reaction is performed in three steps: (1) phosphoric acid reacts with vanillin to form phosphate esters with higher reactivity of the carbonyl group, known as the SPV reagent; (2) unsaturated lipids react with concentrated sulfuric acid $(\geq 95 \%)$ at high temperatures $\left(90-100^{\circ} \mathrm{C}\right)$ to form a carbonium ion; (3) the ensuing lipid products react with the SPV reagent, whereby the carbonium ion reacts with the carbonyl group of a phosphovanillin ester to form a pink chromophore compound that is stabilized by resonance [189]. Quantification is then performed by measuring absorbance at $530 \mathrm{~nm}$.

The SPV method has been recommended for routine analysis; however, the presence of either double bonds or free hydroxyl groups is required for a positive SPV reaction [190]. To this end, its accuracy depends primarily on the reference standard being used. Color intensity varies between different lipids due to structural differences in fatty acids. A higher unsaturated fatty acids content leads to higher intensities; however, the presence of polyunsaturated fatty acids does not translate in a more intense color because of steric hindrance [191]. For example, triolein resulted in higher color intensity compared to the polyunsaturated eicosapentaenoic and docosahexaenoic acids, whereas unsaturated fatty acids did not react with the SPV reagent, as expected. [191]. This observation led the authors to conclude that the reaction was affected by the samples' concentration and chemical structure. Various colorimetric methods applied for lipid quantification of oleaginous microorganisms are presented in Table 9.

The SPV method has been modified for high-throughput analysis of total lipids in a 96-well microplate using solvent-extracted and purified lipid samples [193]. The microplate procedure included the addition of $<100 \mu \mathrm{L}$ of sample and had a detection range of 5-120 $\mu \mathrm{g}$ lipids. The microplate assay showed a strong correlation with the gravimetric method for the analysis of four green microalgae strains. Anschau et al. (2017) adapted the SPV method to a 96-well microplate assay, eliminating the first step of organic solvent addition (chloroform), and verified the impact of unsaturated and saturated fatty acids as a reference on the validation parameters of the method [190]. No significant difference in lipid determination was found between this and the gravimetric method, suggesting that the SPV approach could be a useful analytical tool to quantify lipids in lyophilized yeast and microalgae cells.

The SPV assay has advantages over traditional extraction and gravimetric analysis, as well as high-throughput fluorescence spectroscopy. Compared to Folch extraction and gravimetric quantification, both of which may lead to overestimating lipid content due to inclusion of other lipophilic compounds (e.g., lipophilic proteins and pigments), the SPV assay eliminates these issues as these products are degraded by acid-thermal treatment. Compared to Nile Red, which can undergo rapid photobleaching, the color formed in the SPV reaction remains stable for several hours even under abundant light [194]. One drawback of the SPV method is that it requires lipid extraction through addition of chloroform and subsequent sample purification. 


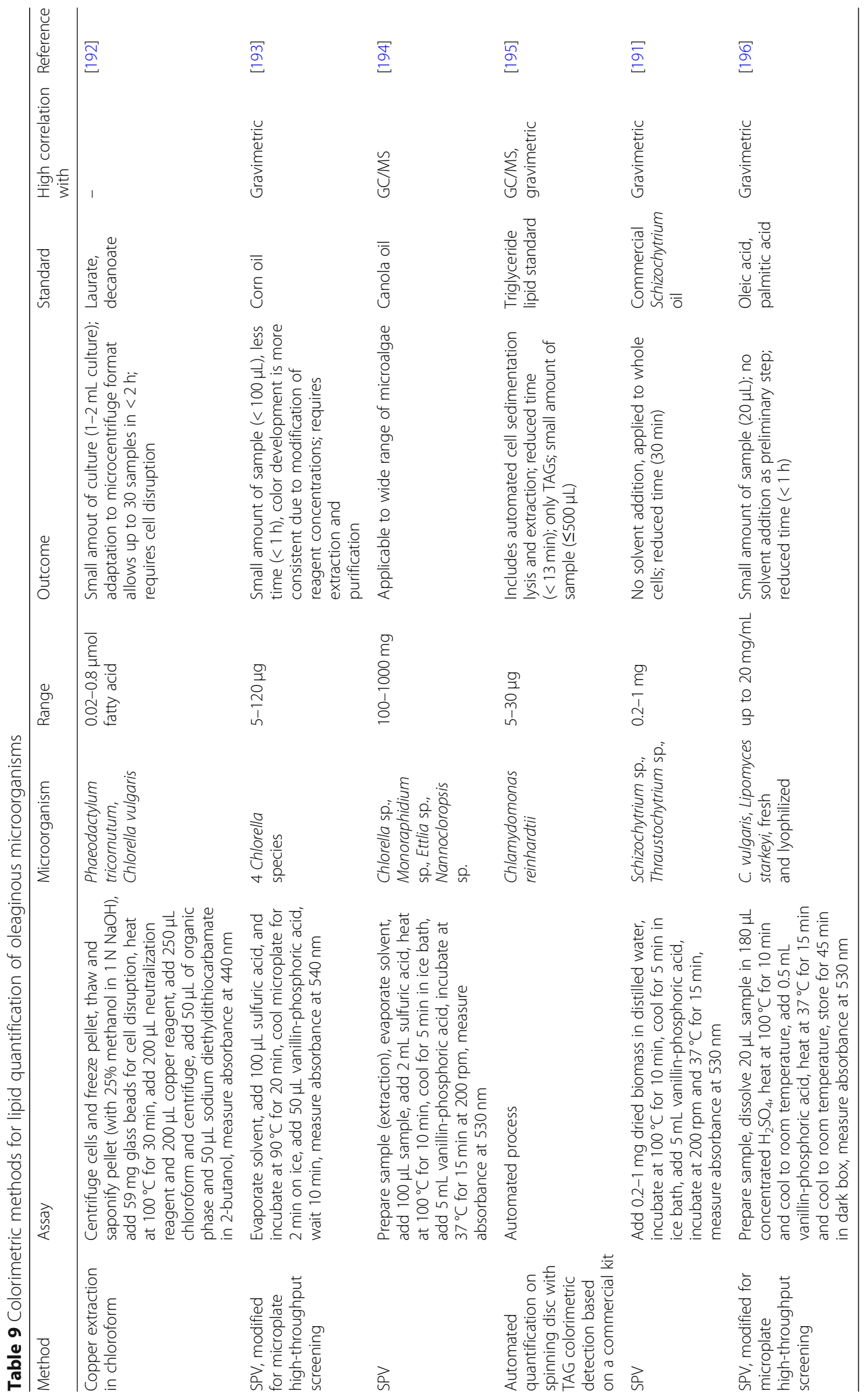


The colorimetric quantification of algal fatty acids dissolved in chloroform has been described by Wawrik and Harriman (2010) based on a method initially developed by Duncombe (1963) [192]. The assay includes the hydrolysis of algal lipids to their corresponding fatty acids, followed by extraction of their copper salts with chloroform. Finally, the amount of copper is determined colorimetrically at $440 \mathrm{~nm}$ following addition of diethyldithiocarbamate and generation of a yellow product. Adaptation of the protocol to a microcentrifuge tube with $1 \mathrm{~mL}$ of log-phase algal culture allowed quantification of 24-30 samples in less than $1 \mathrm{~h}$. The assay produced a linear response for all long-chain fatty acids. Whereas the extinction coefficient was significantly higher in C12:0 than C10:0 fatty acids; it remained largely indistinguishable in C12:0, C14:0, and C16:0 fatty acids. Moreover, unsaturation had a small but significant effect, as did functional groups, suggesting that chemical modification could lead to an underestimation of the total lipid content with this method.

Kim et al. (2015) developed a fully integrated centrifugal microfluidic device for rapid on-site automated quantification of lipids from microalgal samples, involving small sample volumes $(\leq 500 \mu \mathrm{L})$ and short times ( $\leq 13 \mathrm{~min})$ [195]. The serial process included optimized steps of cell sedimentation and lysis, liquid-liquid extraction using $n$-hexane:ethanol, and colorimetric detection by a commercial TAG assay kit. The colorimetric assay involved the following reactions: enzymatic hydrolysis of lipids by a lipase generating glycerol and free fatty acids, the phosphorylation of glycerol to glycerol-3-phosphate by a kinase, oxidation of the latter to dihydroxyacetone phosphate by a glycerol phosphate oxidase, and finally the conversion of the oxidized product to quinoneimine dye by a peroxidase. The dye product was quantified by measuring absorbance at $540 \mathrm{~nm}$. The highly linear correlation $\left(R^{2}>0.99\right)$ between the quantity of lipids determined by the fully automated lab-on-a-disc and either manual extraction or conventional GC/MS suggested high accuracy of the developed device. This, however, was countered by a relatively high error in the measured amounts of microalgal lipids, particularly at low sample concentrations. The error was attributed mainly to sample preparation and the contribution of other lipids during $\mathrm{GC} / \mathrm{MS}$ detection.

\section{Comparison of conventional and high-throughput lipid measurements}

As discussed previously, the selection of an appropriate method depends on its suitability for the chosen microbial strain and the specific experimental conditions. Conventional methods of lipid quantification rely on lipid extraction by solvents, which is often time consuming, insensitive to small differences in lipid content, and requires a substantial amount of cell material and toxic solvents. Furthermore, as the traditional gravimetric method involves several steps, neutral lipids can be lost along the way [180]. Another drawback of gravimetric analysis is that it estimates all lipids, not just neutral ones. Nevertheless, the gravimetric method remains the most common way to quantify lipids and it can be considered a standard when developing new screening strategies. Compared to the traditional gravimetric method, fluorescence measurements can offer a simpler, faster, and less biomass-requiring way of determining lipid content. Also, sensitivity is higher, allowing for small differences in lipid content to be distinguished [137]. On the downside, fluorescence-based detection is highly species- and strain-specific, and these methods require optimization before they can become reliable quantification tools. The Nile Red method might either over- or underestimate neutral lipid content as it strongly depends on the dye diffusing into cells, and the presence and concentrations of pigments or other lipophilic compounds affecting the fluorescence background [180]. Other methods such as TD-NMR and SPV are species-specific and their accuracy varies among species. Accordingly, their protocol requires some modifications before unknown samples can be accurately analyzed [33]. Raman spectrometric methods can be applied to single cells, but they do not show good accuracy with samples containing fluorescent pigments and carotenoids [145]. Moreover, lipid quantification is based on the degree of unsaturation of fatty acids and further calibration with other methods such as the gravimetric one is needed [197]. High costs associated with sample preparation for TLC/ HPTLC hinder their application on a large scale. A comparison of all conventional and non-conventional methods is presented in Table 10 and is aimed to provide a guide for identifying the most suitable method.

\section{Conclusions}

Methods for microbial lipid analysis should be selected based on their suitability to the species being examined. In oleaginous microorganisms, the choice depends on the desired level of identification. If crude lipid content or total neutral lipids and/or lipid classes are the targets, gravimetric, fluorescence, and FTIR methods, respectively, should be attempted. Conversely, the types of fatty acids, their length, and level of saturation/unsaturation can be quantified most reliably by NMR, Raman spectrometry, and GC FID/MS, respectively. The estimation may vary with the size and stage (wet or dry) of samples required for a particular method: $1 \mathrm{~g}$ of dry biomass for NMR, 5 to $500 \mathrm{mg}$ wet biomass for chromatography or MS, $1 \mathrm{ml}$ of culture for colorimetric methods, $5 \mu \mathrm{L}$ of culture for fluorescence estimation, and single cells for Raman spectrometry. Lipid quantification can be relative or absolute depending on the method used. Absolute quantification can be done by gravimetric analysis, GC, 
Table 10 Comparison between conventional and non-conventional methods for lipids determination

\begin{tabular}{|c|c|c|}
\hline Methods & Advantages & Disadvantages \\
\hline \multicolumn{3}{|l|}{ Conventional } \\
\hline Gravimetric & $\begin{array}{l}\text { The easiest method to quantify total lipids in a short time, } \\
\text { no need for special equipment or training }\end{array}$ & $\begin{array}{l}\text { Requires cell disruption, extraction, not suitable for small } \\
\text { amounts of sample }\end{array}$ \\
\hline $\begin{array}{l}\text { Chromatographic } \\
\text { coupled with detector }\end{array}$ & Well-established procedures for lipid profiling & $\begin{array}{l}\text { Requires cell disruption, extraction, and (in situ) } \\
\text { transesterification, multi-step process; Depends on microal- } \\
\text { gae strains and cellular extraction method }\end{array}$ \\
\hline \multicolumn{3}{|l|}{ Non-conventional } \\
\hline FTIR & $\begin{array}{l}\text { Identification of lipid classes on the basis of standards, } \\
\text { cellular content determination without disruption of cells, } \\
\text { small amount of samples }\end{array}$ & $\begin{array}{l}\text { FTIR band shifts are species-specific, cannot differentiate } \\
\text { different species when a mixture of cultures is used }\end{array}$ \\
\hline Raman spectroscopy & $\begin{array}{l}\text { Label-free, no sample preparation, in vivo analysis, } \\
\text { real-time, non-destructive }\end{array}$ & $\begin{array}{l}\text { Fluorescent pigments and carotenoids interfere with } \\
\text { analysis; quantification is focused mainly on determining } \\
\text { the degree of unsaturation, there is need for calibration } \\
\text { based on other methods such as gravimetric analysis; } \\
\text { difficult to translate to an industrial setting }\end{array}$ \\
\hline NMR & $\begin{array}{l}\text { Can be non-destructive, application to whole cells, } \\
\text { extracted and transesterified lipids }\end{array}$ & $\begin{array}{l}\text { Need for internal standards for quantification; difficult to } \\
\text { translate to an industrial setting }\end{array}$ \\
\hline Dielectric spectroscopy & $\begin{array}{l}\text { Rapid, non-invasive, and label-free method; potential for } \\
\text { automated process for biomonotring }\end{array}$ & Total lipid detection, no profiling \\
\hline $\begin{array}{l}\text { Fluorescence } \\
\text { spectrometry }\end{array}$ & High-throughput potential & $\begin{array}{l}\text { Uptake and intensity depends on dye and cell wall; only } \\
\text { detects neutral lipids }\end{array}$ \\
\hline Nile Red & Mostly used in literature & $\begin{array}{l}\text { Photo-bleaching of agent; poor penetration of cells; } \\
\text { interference with chlorophyll autofluorescence and green } \\
\text { fluorophores; limited specificity to lipids }\end{array}$ \\
\hline BODIPY 505/515 & $\begin{array}{l}\text { More lipid-specific, narrower emission spectrum, higher } \\
\text { sensitivity, and better reproducibility, requires lower } \\
\text { concentration of solvent carrier }\end{array}$ & Interference with green fluorophores \\
\hline AC-202 & More sensitive than BODIPY; low-background signal & Not used for quantification yet \\
\hline Colorimetry & $\begin{array}{l}\text { High-throughput potential } \\
\text { Low cost }\end{array}$ & Total lipid detection only \\
\hline SPV & $\begin{array}{l}\text { Color formation is stable for hours } \\
\text { Fast, low detection limit } \\
\text { Solvent extraction can be omitted depending on the assay }\end{array}$ & $\begin{array}{l}\text { Requires presence of double bond or free hydroxyl groups } \\
\text { (unsaturated lipids) } \\
\text { Is dependent on standard }\end{array}$ \\
\hline TAG kit & Fast, automated process & Detects only TAGs; requires cell disruption and extraction \\
\hline Copper extraction & $\begin{array}{l}\text { Fast, high detection limit, can be adapted to } \\
\text { microcentrifuge format }\end{array}$ & Requires solvent addition and cell disruption \\
\hline
\end{tabular}

MS, and by direct transesterification methods; whereas relative quantification (unless using a standard) can be done with FTIR, fluorescence probes, colorimetric, NMR, and Raman spectrometry. With some methods, cultures remain viable at the end of the quantification procedure, as in the case of NMR, Raman spectrometry, and sometimes Nile Red staining. If a fast screening of lipid content is required, a high-throughput Nile Red flurospectrophotometric method can be used, however it is often not comparable between different species. Finally, the selection of a lipid quantification method is dictated by the accessibility of equipment and resources in the laboratory; preferably, it should favor the most significant and universally accepted ones.

\section{Abbreviations}

BODIPY: Boron-dipyrromethene; CARS: Coherent anti-Stokes Raman scattering; CRS: Confocal Raman spectroscopy; DAGs: Diacylglycerols;
DMSO: Dimethyl sulfoxide; DTD: Direct thermal desorption; EDTA: Ethylenediaminetetraacetic acid; ELSD: Evaporative light scattering detector; ESI: Electrospray ionization; FABMS: Fast atom bombardment mass spectrometry; FACS: Fluorescence-activated cell sorting; FAME: Fatty acid methyl esters; FID: Flame ionization detector; FTIR: Fourier transform infrared spectroscopy; GC: Gas chromatography; HPLC: High-performance liquid chromatography; HPTLC: High-performance thin-layer chromatography; HRMAS: High-resolution magic angle spinning; iMQC: Intermolecular multiplequantum coherence; IR: Infrared; LTRS: Laser-trapping Raman spectroscopy; MAGs: Monoacylglycerols; MALDI: Matrix-assisted laser desorption and ionization; MS: Mass spectrometry; NIR: Near-infrared; NMR: Nuclear magnetic resonance; SPV: Sulfo-phospho-vanillin; TAGs: Triacylglycerols; TD: Time domain; TLC: Thin-layer chromatography; TOF: Time-of-flight; UV: Ultraviolet

\section{Acknowledgements}

Not applicable.

\section{Funding}

We would like to thank Bio4Energy, a strategic research environment appointed by the Swedish government for providing funding for the current work. 


\section{Availability of data and materials}

Data sharing not applicable to this article as no datasets were generated or analyzed during the current study.

\section{Authors' contributions}

$L M, U R$ and $P C$ conceived the content of the article and revised the text. AP $I A$, and JE analyzed the literature and wrote the paper. All authors read and approved the final manuscript.

\section{Competing interests}

The authors declare that they have no competing interests.

\section{Publisher's Note}

Springer Nature remains neutral with regard to jurisdictional claims in published maps and institutional affiliations.

Received: 15 January 2019 Accepted: 2 April 2019

Published online: 05 June 2019

\section{References}

1. Cho HU, Park JM. Biodiesel production by various oleaginous microorganisms from organic wastes. Bioresour Technol. 2018; 256(December 2017):502-8. https://doi.org/10.1016/j.biortech.2018.02.010.

2. Miazek K, Remacle C, Richel A, Goffin D. Beech wood Fagus sylvatica diluteacid hydrolysate as a feedstock to support Chlorella sorokiniana biomass, fatty acid and pigment production. Bioresour Technol. 2017;230:122-31.

3. Li X, Xu H, Wu Q. Large-scale biodiesel production from microalga Chlorella protothecoides through heterotrophic cultivation in bioreactors. Biotechnol Bioeng. 2007;98:764-71. https://doi.org/10.1002/bit.21489.

4. Abomohra AEF, El-Sheekh M, Hanelt D. Screening of marine microalgae isolated from the hypersaline Bardawil lagoon for biodiesel feedstock. Renew Energy. 2017;101:1266-72. https://doi.org/10.1016/j.renene.2016.10.015.

5. Shen X-F, Chu F-F, Lam PKS, Zeng RJ. Biosynthesis of high yield fatty acids from Chlorella vulgaris NIES-227 under nitrogen starvation stress during heterotrophic cultivation. Water Res. 2015;81:294-300. https://doi.org/10. 1016/j.watres.2015.06.003.

6. Patel A, Matsakas L, Rova U, Christakopoulos P. Heterotrophic cultivation of Auxenochlorella protothecoides using forest biomass as a feedstock for sustainable biodiesel production. Biotechnol Biofuels. 2018;11:169. https:// doi.org/10.1186/s13068-018-1173-1

7. Rao AR, Dayananda C, Sarada R, Shamala TR, Ravishankar GA. Effect of salinity on growth of green alga Botryococcus braunii and its constituents. Bioresour Technol. 2007;98:560-4.

8. Karpagam R, Preeti R, Ashokkumar B, Varalakshmi P. Ecotoxicology and environmental safety enhancement of lipid production and fatty acid profiling in Chlamydomonas reinhardtii, CC1010 for biodiesel production. Ecotoxicol Environ Saf. 2015;121:253-7. https://doi.org/10.1016/j.ecoenv.2015.03.015.

9. Patel A, Mikes F, Bühler S, Matsakas L. Valorization of brewers' spent grain for the production of lipids by oleaginous yeast. Molecules. 2018;23:3052. https://doi.org/10.3390/molecules23123052.

10. Bonturi N, Matsakas L, Nilsson R, Christakopoulos P, Miranda EA, Berglund KA, et al. Single cell oil producing yeasts Lipomyces starkeyi and Rhodosporidium toruloides: selection of extraction strategies and biodiesel property prediction. Energies. 2015;8:5040-52.

11. Xue F, Miao J, Zhang X, Luo H, Tan T. Studies on lipid production by Rhodotorula glutinis fermentation using monosodium glutamate wastewater as culture medium. Bioresour Technol. 2008;99:5923-7. https:// doi.org/10.1016/j.biortech.2007.04.046.

12. Patel A, Matsakas L. A comparative study on de novo and ex novo lipid fermentation by oleaginous yeast using glucose and sonicated waste cooking oil. Ultrason Sonochem. 2018. https:/doi.org/10.1016/j.ultsonch.2018.12.010.

13. Matsakas L, Sterioti A, Rova U, Christakopoulos P. Use of dried sweet sorghum for the efficient production of lipids by the yeast Lipomyces starkeyi CBS 1807. Ind Crop Prod. 2014;62:367-72. https://doi.org/10.1016/j. indcrop.2014.09.011.

14. Matsakas L, Giannakou M, Vörös D. Effect of synthetic and natural media on lipid production from fusarium oxysporum. Electron J Biotechnol. 2017;30: 95-102.

15. Yang $Y$, Hu B. Investigation on the cultivation conditions of a newly isolated fusarium fungal strain for enhanced lipid production. Appl Biochem Biotechnol. 2018. https://doi.org/10.1007/s12010-018-2870-8.
16. Nouri H, Moghimi H, Nikbakht Rad M, Ostovar M, Farazandeh Mehr SS, Ghanaatian F, et al. Enhanced growth and lipid production in oleaginous fungus, Sarocladium kiliense ADH17: study on fatty acid profiling and prediction of biodiesel properties. Renew Energy. 2019;135:10-20. https:// doi.org/10.1016/j.renene.2018.11.104.

17. Eroshin VK, Satroutdinov AD, Dedyukhina EG, Chistyakova TI. Arachidonic acid production by Mortierella alpina with growth-coupled lipid synthesis. Process Biochem. 2000;35:1171-5.

18. Subhash GV, Mohan SV. Bioresource technology biodiesel production from isolated oleaginous fungi Aspergillus sp. using corncob waste liquor as a substrate. Bioresour Technol. 2011;102:9286-90. https://doi.org/10.1016/j. biortech.2011.06.084.

19. Kosa M, Ragauskas AJ. Lignin to lipid bioconversion by oleaginous Rhodococci. Green Chem. 2013;15:2070-4.

20. Kumar S, Gupta N, Pakshirajan K. Simultaneous lipid production and dairy wastewater treatment using Rhodococcus opacus in a batch bioreactor for potential biodiesel application. J Environ Chem Eng. 2015;3:1630-6. https:// doi.org/10.1016/j.jece.2015.05.030.

21. Goswami L, Tejas Namboodiri MM, Vinoth Kumar R, Pakshirajan K, Pugazhenthi G. Biodiesel production potential of oleaginous Rhodococcus opacus grown on biomass gasification wastewater. Renew Energy. 2017;105: 400-6. https://doi.org/10.1016/j.renene.2016.12.044.

22. Gouda MK, Omar SH, Aouad LM. Single cell oil production by Gordonia sp. DG using agro-industrial wastes. World J Microbiol Biotechnol. 2008;24:1703-11.

23. Kurosawa K, Wewetzer SJ, Sinskey AJ. Engineering xylose metabolism in triacylglycerol-producing Rhodococcus opacus for lignocellulosic fuel production. Biotechnol Biofuels. 2013;6:1-13.

24. Ratledge C, Wynn JP. The biochemistry and molecular biology of lipid accumulation in oleaginous microorganisms. Adv Appl Microbiol. 2002;51:1-51.

25. Kolouchová I, Matátková O, Sigler K, Masák J, Řezanka T. Lipid accumulation by oleaginous and non-oleaginous yeast strains in nitrogen and phosphate limitation. Folia Microbiol (Praha). 2016;61:431-8.

26. Mata TM, Martins AA, Caetano NS. Microalgae for biodiesel production and other applications: a review. Renew Sust Energ Rev. 2010;14:217-32. https:// doi.org/10.1016/j.rser.2009.07.020.

27. Meng X, Yang J, Xu X, Zhang L, Nie Q, Xian M. Biodiesel production from oleaginous microorganisms. Renew Energy. 2009;34:1-5. https://doi.org/10. 1016/j.renene.2008.04.014.

28. Sitepu IR, Garay LA, Sestric R, Levin D, Block DE, German JB, et al. Oleaginous yeasts for biodiesel: current and future trends in biology and production. Biotechnol Adv. 2014;32:1336-60. https://doi.org/10.1016/j. biotechadv.2014.08.003.

29. Levering J, Broddrick J, Zengler K. Engineering of oleaginous organisms for lipid production. Curr Opin Biotechnol. 2015;36:32-9. https://doi.org/10. 1016/j.copbio.2015.08.001.

30. Mubarak M, Shaija A, Suchithra TV. A review on the extraction of lipid from microalgae for biodiesel production. Algal Res. 2015;7:117-23. https://doi. org/10.1016/j.algal.2014.10.008

31. Lee TH, Chang JS, Wang HY. Current developments in high-throughput analysis for microalgae cellular contents. Biotechnol J. 2013;8:1301-14.

32. Elsey D, Jameson D, Raleigh B, Cooney MJ. Fluorescent measurement of microalgal neutral lipids. J Microbiol Methods. 2007;68:639-42. https://doi. org/10.1016/j.mimet.2006.11.008.

33. Hounslow E, Noirel J, Gilmour DJ, Wright PC. Lipid quantification techniques for screening oleaginous species of microalgae for biofuel production. Eur J Lipid Sci Technol. 2017;119:1-24.

34. Rumin J, Bonnefond H, Saint-Jean B, Rouxel C, Sciandra A, Bernard O, et al. The use of fluorescent Nile red and BODIPY for lipid measurement in microalgae. Biotechnol Biofuels. 2015;8:1-16.

35. Alemán-Nava GS, Cuellar-Bermudez SP, Cuaresma M, Bosma R, Muylaert K, Ritmann BE, et al. How to us Nile red, a selective fluorescent stain for microalgal neutral lipids. J Microbiol Methods. 2016;128:74-9.

36. De la Hoz SH, Ayidzoe W, Ben-Zvi A, Burrell REE, McCaffrey WCC. Improving the reliability of fluorescence-based neutral lipid content measurements in microalgal cultures. Algal Res. 2012;1:176-84. https://doi.org/10.1016/j.algal. 2012.07.004.

37. Cooksey KE, Guckert JB, Williams SA, Callis PR. Fluorometric determination of the neutral lipid content of microalgal cells using Nile red. J Microbiol Methods. 1987;6:333-45. https://doi.org/10.1016/0167-7012(87)90019-4.

38. Ami D, Posteri R, Mereghetti P, Porro D, Doglia SM, Branduardi P. Fourier transform infrared spectroscopy as a method to study lipid accumulation in 
oleaginous yeasts. Biotechnol Biofuels. 2014;7:12. https://doi.org/10.1186/ 1754-6834-7-12.

39. Sarpal AS, Teixeira CMLL, Silva PRM, da Costa Monteiro TV, da Silva Jl, da Cunha VS, et al. NMR techniques for determination of lipid content in microalgal biomass and their use in monitoring the cultivation with biodiesel potential. Appl Microbiol Biotechnol. 2016;100:2471-85.

40. Signori L, Ami D, Posteri R, Giuzzi A, Mereghetti P, Porro D, et al. Assessing an effective feeding strategy to optimize crude glycerol utilization as sustainable carbon source for lipid accumulation in oleaginous yeasts. Microb Cell Factories. 2016:15:1-19.

41. Fon Sing S, Isdepsky A, Borowitzka MA, Moheimani NR. Production of biofuels from microalgae. Mitig Adapt Strateg Glob Chang. 2013;18:47-72.

42. Sarpal AS, Silva PRM, Martins JL, Amaral JJ, Monnerat MM, Cunha VS, et al. Biodiesel potential of oleaginous yeast biomass by NMR spectroscopic techniques. Energy Fuels. 2014;28:3766-77.

43. Patel A, Arora N, Mehtani J, Pruthi V, Pruthi PA. Assessment of fuel properties on the basis of fatty acid profiles of oleaginous yeast for potential biodiesel production. Renew Sustain Energy Rev. 2017;77(March) 604-16. https://doi.org/10.1016/j.rser.2017.04.016.

44. Bigelow NW, Hardin WR, Barker JP, Ryken SA, MacRae AC, Cattolico RA. A comprehensive GC-MS sub-microscale assay for fatty acids and its applications. J Am Oil Chem Soc. 2011;88:1329-38.

45. Li L, Han J, Wang Z, Liu J, Wei J, Xiong S, Zhao Z. Mass spectrometry methodology in lipid analysis. Int J Mol Sci. 2014;15:10492-507.

46. Halim R, Danquah MK, Webley PA. Extraction of oil from microalgae for biodiesel production: a review. Biotechnol Adv. 2012;30:709-32. https://doi. org/10.1016/j.biotechadv.2012.01.001.

47. Raventos M, Duarte S, Alarcon R. Application and possibilities of supercritical $\mathrm{CO} 2$ extraction in food processing industry: an overview. Food Sci Technol Int. 2002:8:269-84. https://doi.org/10.1177/1082013202008005451.

48. Safi C, Camy S, Frances C, Varela MM, Badia EC, Pontalier PY, et al. Extraction of lipids and pigments of Chlorella vulgaris by supercritical carbon dioxide: influence of bead milling on extraction performance. J Appl Phycol. 2014;26:1711-8.

49. Sahena F, Zaidul ISM, Jinap S, Karim AA, Abbas KA, Norulaini NAN, et al. Application of supercritical CO2in lipid extraction - a review. J Food Eng. 2009;95:240-53. https://doi.org/10.1016/j.jfoodeng.2009.06.026.

50. Santana A, Jesus S, Larrayoz MA, Filho RM. Supercritical carbon dioxide extraction of algal lipids for the biodiesel production. Procedia Eng. 2012; 42(August):1755-61.

51. Sharif KM, Rahman MM, Azmir J, Mohamed A, Jahurul MHA, Sahena F, et al. Experimental design of supercritical fluid extraction - a review. J Food Eng. 2014;124:105-16.

52. Paudel A, Jessop MJ, Stubbins SH, Champagne P, Jessop PG. Extraction of lipids from microalgae using $\mathrm{CO}_{2}$-expanded methanol and liquid $\mathrm{CO} 2$. Bioresour Technol. 2015;184:286-90. https://doi.org/10.1016/j.biortech.2014.11.111.

53. Orellana JL, Smith TD, Kitchens CL. Liquid and supercritical CO2extraction of fat from rendered materials. J Supercrit Fluids. 2013;79:55-61. https://doi. org/10.1016/j.supflu.2013.01.022.

54. Cheng J, Sun J, Huang Y, Zhou J, Cen K. Fractal microstructure characterization of wet microalgal cells disrupted with ultrasonic cavitation for lipid extraction. Bioresour Technol. 2014;170:138-43. https://doi.org/10. 1016/j.biortech.2014.07.090

55. Tan XB, Lam MK, Uemura Y, Lim JW, Wong CY, Lee KT. Cultivation of microalgae for biodiesel production: a review on upstream and downstream processing. Chinese J Chem Eng. 2018;26:17-30. https://doi. org/10.1016/j.cjche.2017.08.010

56. Ambat I, Srivastava V, Sillanpää M. Recent advancement in biodiesel production methodologies using various feedstock: a review. Renew Sust Energ Rev. 2018; 90(February 2017):356-69. https:/doi.org/10.1016/.j.ser.2018.03.069.

57. Postma PR, Miron TL, Olivieri G, Barbosa M, Wijfels RH, Eppink MHM. Mild disintegration of the green microalgae Chlorella vulgaris using bead milling. Bioresour Technol. 2015;184:297-304. https://doi.org/10.1016/.j.biortech.2014.09.033.

58. Dejoye Tanzi C, Abert Vian M, Chemat F. New procedure for extraction of algal lipids from wet biomass: a green clean and scalable process. Bioresour Technol. 2013;134:271-5. https://doi.org/10.1016/j.biortech.2013.01.168.

59. Byreddy AR, Gupta A, Barrow CJ, Puri M. Comparison of cell disruption methods for improving lipid extraction from thraustochytrid strains. Mar Drugs. 2015;13:5111-27.

60. Park JY, Lee K, Choi SA, Jeong MJ, Kim B, Lee JS, et al. Sonication-assisted homogenization system for improved lipid extraction from Chlorella vulgaris. Renew Energy. 2015;79:3-8. https://doi.org/10.1016/j.renene.2014.10.001.
61. Kwak M, Kang SG, Hong WK, Han Jl, Chang YK. Simultaneous cell disruption and lipid extraction of wet aurantiochytrium sp. KRS101 using a high shear mixer. Bioprocess Biosyst Eng. 2018;41:671-8.

62. Sathish A, Sims RC. Biodiesel from mixed culture algae via a wet lipid extraction procedure. Bioresour Technol. 2012;118:643-7. https://doi.org/10. 1016/j.biortech.2012.05.118.

63. Yusaf T, Al-Juboori RA. Alternative methods of microorganism disruption for agricultural applications. Appl Energy. 2014;114:909-23.

64. Randall RC, Lee H, Ozretich RJ, Lake JL, Pruell RJ. Evaluation of selected lipid methods for normalizing pollutant bioaccumulation. Environ Toxicol Chem. 1991;10:1431-6.

65. Randall RC, Young DR, Lee H, Echols SF. Lipid methodology and pollutant normalization relationships for neutral nonpolar organic pollutants. Environ Toxicol Chem. 1998;17:788-91.

66. Hu Q, Sommerfeld M, Jarvis E, Ghirardi M, Posewitz M, Seibert M, et al. Microalgal triacylglycerols as feedstocks for biofuel production: perspectives and advances. Plant J. 2008:54:621-39.

67. Uduman N, Qi Y, Danquah MK, Forde GM, Hoadley A. Dewatering of microalgal cultures: a major bottleneck to algae-based fuels. J Renew Sustain Energy. 2010;2:1-15.

68. Folch J, Lees M, Sloane Stanley G. A simple method of isolation and purification of total lipids from animal tissues. J Biol Chem. 1957;226:497-509.

69. Bligh E, Dyler WJ. A rapid method of total lipid extraction and purification. Can J Biochem Physiol. 1959;37:911-7.

70. Van Handel E. Rapid determination of total lipids in mosquitoes. J Am Mosq Control Assoc. 1985;1:302-4.

71. Cheng CH, Du TB, Pi HC, Jang SM, Lin YH, Lee HT. Comparative study of lipid extraction from microalgae by organic solvent and supercritical $\mathrm{CO} 2$. Bioresour Technol. 2011;102:10151-3.

72. White S, Anandraj A, Bux F. PAM fluorometry as a tool to assess microalgal nutrient stress and monitor cellular neutral lipids. Bioresour Technol. 2011; 102:1675-82. https://doi.org/10.1016/j.biortech.2010.09.097.

73. McNichol J, MacDougall KM, Melanson JE, McGinn PJ. Suitability of soxhlet extraction to quantify microalgal fatty acids as determined by comparison with in situ transesterification. Lipids. 2012;47:195-207.

74. Patel A, Pravez M, Deeba F, Pruthi V, Singh RP, Pruthi PA. Boosting accumulation of neutral lipids in Rhodosporidium kratochvilovae HIMPA1 grown on hemp (Cannabis sativa Linn) seed aqueous extract as feedstock for biodiesel production. Bioresour Technol. 2014;165(C):214-22. https://doi. org/10.1016/.j.biortech.2014.03.142.

75. Privett OS, Blank ML, Codding DW, Nickell EC. Lipid analysis by quantitative thin-layer chromatography. J Am Oil Chem Soc. 1965;42:381-93 https://link. springer.com/article/10.1007/BF02635573.

76. Peterson BL, Cummings BS. A review of chromatographic methods for the assessment of phospholipids in biological samples. Biomed Chromatogr. 2006;20:227-43

77. Dyńska-Kukulska K, Ciesielski W. Methods of extraction and thin-layer chromatography determination of phospholipids in biological samples. Rev Anal Chem. 2012:31:43-56.

78. Fuchs B, Süß R, Teuber K, Eibisch M, Schiller J. Lipid analysis by thin-layer chromatography-a review of the current state. J Chromatogr A. 2011;1218: 2754-74. https://doi.org/10.1016/j.chroma.2010.11.066.

79. Beattie SE, Johnson LA, Hammond EG, Dixon PM. Lipid synthesis and encapsulation by Cryptococcus curvatus by Major: food science and technology program of study committee; 2009.

80. Tsigie YA, Wang C-Y, Truong C-T, Ju Y, Asteraye Y, Wang C-Y, et al. Lipid production from Yarrowia lipolytica Polg grown in sugarcane bagasse hydrolysate. Bioresour Technol. 2011;102:9216-22. https://doi.org/10.1016/j. biortech.2011.06.047.

81. Gauglitz EJ, Malins DC. The preparation of polyunsaturated aliphatic aldehydes via the acyloin condensation. J Am Oil Chem Soc. 1960;37:425-7.

82. Karlsson K-A, Norrby A, Samuelsson B. Use of thin-layer chromatography for the preliminary diagnosis of Refsum's disease (Heredopathia atactica polyneuritiformis). Biochim Biophys Acta - Lipids Lipid Metab. 1967;144:1624. https://doi.org/10.1016/0005-2760(67)90089-6.

83. Perona J, Gutierrez V. Analysis of neutral lipids: triacylglycerols. In: Handbook of food analysis: physical characterization and nutrient analysis; 2004. p. 275-312.

84. Christie WW. Rapid separation and quantification of lipid classes by high performance liquid chromatography and mass (light-scattering) detection. J Lipid Res. 1985;26:507-12. 
85. Ross MM, Neihof RA, Campana JE. Direct fatty acid profiling of complex lipids in intact algae by fast-atom-bombardment mass spectrometry. Anal Chim Acta. 1986;181(C):149-57.

86. Fuchs B, Süß R, Schiller J. An update of MALDI-TOF mass spectrometry in lipid research. Prog Lipid Res. 2010;49:450-75. https://doi.org/10.1016/j. plipres.2010.07.001.

87. Liu J, Wang H, Manicke NE, Lin J, Cooks RG. Application of paper spray ionization development, characterization, and application of paper spray ionization. Anal Chem. 2010;82:2463-71.

88. Rězanka T, Vokoun J, Slavíček J, Podojil M. Determination of fatty acids in algae by capillary gas chromatography-mass spectrometry. J Chromatogr A. 1983;268(C):71-8.

89. Lu N, Wei D, Jiang XL, Chen F, Yang ST. Fatty acids profiling and biomarker identification in snow alga Chlamydomonas Nivalis by $\mathrm{NaCl}$ stress using GC/ MS and multivariate statistical analysis. Anal Lett. 2012;45:1172-83.

90. Barupal DK, Kind T, Kothari SL, Lee DY, Fiehn O. Hydrocarbon phenotyping of algal species using pyrolysis-gas chromatography mass spectrometry. BMC Biotechnol. 2010;10:1-9.

91. Biller P, Ross AB. Pyrolysis GC-MS as a novel analysis technique to determine the biochemical composition of microalgae. Algal Res. 2014;6(PA):91-7. https://doi.org/10.1016/j.algal.2014.09.009.

92. Danielewicz MA, Anderson LA, Franz AK. Triacylglycerol profiling of marine microalgae by mass spectrometry. J Lipid Res. 2011;52:2101-8. https://doi. org/10.1194/jlr.D018408.

93. Akoto L, Stellaard F, Irth H, Vreuls RJJ, Pel R. Improved fatty acid detection in micro-algae and aquatic meiofauna species using a direct thermal desorption interface combined with comprehensive gas chromatographytime-of-flight mass spectrometry. J Chromatogr A. 2008;1186:254-61.

94. Oradu SA, Cooks RG. Multistep mass spectrometry methodology for direct characterization of polar lipids in green microalgae using paper spray ionization. Anal Chem. 2012;84:10576-85.

95. Samburova V, Lemos MS, Hiibel S, Kent Hoekman S, Cushman JC, Zielinska B. Analysis of triacylglycerols and free fatty acids in algae using ultraperformance liquid chromatography mass spectrometry. J Am Oil Chem Soc. 2013;90:53-64.

96. Kobayashi N, Noel EA, Barnes A, Rosenberg J, Dirusso C, Black P, et al. Rapid detection and quantification of triacylglycerol by HPLC-ELSD in chlamydomonas reinhardtii and chlorella strains. Lipids. 2013;48:1035-49.

97. Mansour MP. Reversed-phase high-performance liquid chromatography purification of methyl esters of C16-C28 polyunsaturated fatty acids in microalgae, including octacosaoctaenoic acid [28:8(n-3)]. J Chromatogr A. 2005;1097:54-8.

98. Jones J, Manning S, Montoya M, Keller K, Poenie M. Extraction of algal lipids and their analysis by HPLC and mass spectrometry. J Am Oil Chem Soc. 2012:89:1371-81. https://doi.org/10.1007/s11746-012-2044-8.

99. Cavonius LR, Carlsson NG, Undeland I. Quantification of total fatty acids in microalgae: comparison of extraction and transesterification methods. Ana Bioanal Chem. 2014;406:7313-22

100. Hidalgo P, Toro C, Ciudad G, Navia R. Advances in direct transesterification of microalgal biomass for biodiesel production. Rev Environ Sci Biotechnol. 2013;12:179-99.

101. Da Chiu L, Ho SH, Shimada R, Ren NQ, Ozawa T. Rapid in vivo lipid/ carbohydrate quantification of single microalgal cell by Raman spectral imaging to reveal salinity-induced starch-to-lipid shift. Biotechnol Biofuels. 2017;10:1-9.

102. Xiong W, Liu L, Wu C, Yang C, Wu Q. 13C-tracer and gas chromatographymass spectrometry analyses reveal metabolic flux distribution in the oleaginous microalga Chlorella protothecoides. Plant Physiol. 2010;154: 1001-11. https://doi.org/10.1104/pp.110.158956.

103. Akoto L, Pel R, Irth H, Brinkman UAT, Vreuls RJJ. Automated GC-MS analysis of raw biological samples: application to fatty acid profiling of aquatic micro-organisms. J Anal Appl Pyrolysis. 2005;73:69-75.

104. Harris GA, Galhena AS, Fern FM. Ambient sampling / ionization mass spectrometry: applications and current trends. Anal Chem. 2011;83:4508-38.

105. Laurens LML, Knoshaug EP, Rohrer H, Van Wychen S, Dowe N, Zhang M. Solvent-free spectroscopic method for high-throughput, quantitative screening of fatty acids in yeast biomass. Anal Methods. 2019. https://doi. org/10.1039/C8AY02416B.

106. Kosa G, Kohler A, Tafintseva V, Zimmermann B, Forfang K, Afseth NK, et al. Microtiter plate cultivation of oleaginous fungi and monitoring of lipogenesis by high-throughput FTIR spectroscopy. Microb Cell Factories. 2017;16:1-12.
107. Forfang K, Zimmermann B, Kosa G, Kohler A, Shapaval V. FTIR spectroscopy for evaluation and monitoring of lipid extraction efficiency for oleaginous fungi. PLoS One. 2017;12:1-17.

108. Stehfest K, Toepel J, Wilhelm C. The application of micro-FTIR spectroscopy to analyze nutrient stress-related changes in biomass composition of phytoplankton algae. Plant Physiol Biochem. 2005:43:717-26.

109. Matyash V, Liebisch G, Kurzchalia TV, Shevchenko A, Schwudke D. Lipid extraction by methyl- tert -butyl ether for high-throughput lipidomics. J Lipid Res. 2008;49:1137-46. https://doi.org/10.1194/jlr.D700041-JLR200.

110. Driver T, Bajhaiya AK, Allwood JW, Goodacre R, Pittman JK, Dean AP. Metabolic responses of eukaryotic microalgae to environmental stress limit the ability of FT-IR spectroscopy for species identification. Algal Res. 2015;11: 148-55.

111. Mayers JJ, Flynn KJ, Shields RJ. Rapid determination of bulk microalgal biochemical composition by Fourier-Transform Infrared spectroscopy. Bioresour Technol. 2013;148:215-20.

112. Giordano M, Heraud P, Beardall J, Giordano M, Al ET, Kansiz M, et al. Fourier transform infrared spectroscopy as a novel tool to investigate changes in intracellular macromolecular pools in the marine microalga Chaetoceros muellerii (Bacillariophyceae ). J Phycol. 2001;37:271-9.

113. Heraud P, Wood BR, Tobin MJ, Beardall J, McNaughton D. Mapping of nutrient-induced biochemical changes in living algal cells using synchrotron infrared microspectroscopy. FEMS Microbiol Lett. 2005;249:219-25.

114. Sigee DC, Bahrami F, Estrada B, Webster RE, Dean AP. The influence of phosphorus availability on carbon allocation and $P$ quota in Scenedesmus subspicatus: a synchrotron-based FTIR analysis. Phycologia. 2007;46:583-92. https://doi.org/10.2216/07-14.1.

115. James GO, Hocart CH, Hillier W, Chen H, Kordbacheh F, Price GD, et al. Fatty acid profiling of Chlamydomonas reinhardtii under nitrogen deprivation. Bioresour Technol. 2011;102:3343-51. https://doi.org/10.1016/j.biortech.2010.11.051.

116. Dean AP, Sigee DC, Estrada B, Pittman JK. Using FTIR spectroscopy for rapid determination of lipid accumulation in response to nitrogen limitation in freshwater microalgae. Bioresour Technol. 2010;101:4499-507. https://doi. org/10.1016/j.biortech.2010.01.065.

117. Laurens LML, Wolfrum EJ. Feasibility of spectroscopic characterization of algal lipids: Chemometric correlation of NIR and FTIR spectra with exogenous lipids in algal biomass. Bioenergy Res. 2011;4:22-35.

118. Klsner HJ, Brown CW, Kavarnos GJ. Simultaneous determination of triglycerides, phospholipids, and cholesteryl esters by infrared spectrometry. Anal Chem. 1982;54:1479-85.

119. Challagulla V, Nayar S, Walsh K, Fabbro L. Advances in techniques for assessment of microalgal lipids. Crit Rev Biotechnol. 2017;37:566-78.

120. Pollesello P, Toffanin R, Murano E, Paoletti S, Rizzo R, Kvam BJ. Lipid extracts from different algal species:1H and13C-NMR spectroscopic studies as a new tool to screen differences in the composition of fatty acids, sterols and carotenoids. J Appl Phycol. 1992;4:315-22.

121. Sarpal AS, Teixeira CMLL, Silva PRM, Lima GM, Silva SR, Monteiro TV, et al. Determination of lipid content of oleaginous microalgal biomass by NMR spectroscopic and GC-MS techniques. Anal Bioanal Chem. 2015; 407:3799-816.

122. Beal CM, Webber ME, Ruoff RS, Hebner RE. Lipid analysis of Neochloris oleoabundans by liquid state NMR. Biotechnol Bioeng. 2010;106:573-83.

123. Arnold AA, Genard B, Zito F, Tremblay R, Warschawski DE, Marcotte I. Identification of lipid and saccharide constituents of whole microalgal cells by13C solid-state NMR. Biochim Biophys Acta Biomembr. 1848;2015:369-77. https://doi.org/10.1016/j.bbamem.2014.07.017.

124. Akhter M, Dutta Majumdar R, Fortier-McGill B, Soong R, Liaghati-Mobarhan $Y$, Simpson $M$, et al. Identification of aquatically available carbon from algae through solution-state NMR of whole13C-labelled cells. Anal Bioanal Chem. 2016;408:4357-70. https://doi.org/10.1007/s00216-016-9534-8.

125. Davey PT, Hiscox WC, Lucker BF, O'Fallon JV, Chen S, Helms GL. Rapid triacylglyceride detection and quantification in live micro-algal cultures via liquid state1H NMR. Algal Res. 2012;1:166-75. https://doi.org/10.1016/j.algal. 2012.07.003.

126. Bono MS, Garcia RD, Sri-Jayantha DV, Ahner BA, Kirby BJ. Measurement of lipid accumulation in Chlorella vulgaris via flow cytometry and liquidstate1H NMR spectroscopy for development of an NMR-traceable flow cytometry protocol. PLoS One. 2015;10:1-18. https://doi.org/10.1371/journal. pone.0134846

127. Andrew ER. Magic angle spinning in solid state n.m.r. spectroscopy. Philos Trans R Soc A Math Phys Eng Sci. 2006:299:505-20. 
128. Chauton MS, Optun OI, Bathen TF, Volent Z, Gribbestad IS, Johnsen G. HR MAS1H NMR spectroscopy analysis of marine microalgal whole cells. Mar Ecol Prog Ser. 2003;256:57-62.

129. Chauton MS, Størseth TR, Krane J. High-resolution magic angle spinning NMR analysis of whole cells of Chaetoceros muelleri (Bacillariophyceae) and comparison with13C-NMR and distortionless enhancement by polarization transfer13C-NMR analysis of lipophilic extracts. J Phycol. 2004;40:611-8.

130. Wang T, Liu T, Wang Z, Tian X, Yang Y, Guo M, et al. A rapid and accurate quantification method for real-time dynamic analysis of cellular lipids during microalgal fermentation processes in Chlorella protothecoides with low field nuclear magnetic resonance. J Microbiol Methods. 2016;124:13-20. https://doi.org/10.1016/j.mimet.2016.03.003.

131. Al Hattab M, Ghaly A. Microalgae oil extraction pre-treatment methods: critical review and comparative analysis. J Fundam Renew Energy Appl. 2015;5. https://doi.org/10.4172/2090-4541.1000172

132. Gao C, Xiong W, Zhang Y, Yuan W, Wu Q. Rapid quantitation of lipid in microalgae by time-domain nuclear magnetic resonance. J Microbiol Methods. 2008;75:437-40. https://doi.org/10.1016/j.mimet.2008.07.019.

133. Nuzzo G, Gallo C, D'Ippolito G, Cutignano A, Sardo A, Fontana A. Composition and quantitation of microalgal lipids by ERETIC1H NMR method. Mar Drugs. 2013;11:3742-53.

134. Skogen Chauton M, Røvik Størseth T, Johnsen G. High-resolution magic angle spinning $1 \mathrm{H}$ NMR analysis of whole cells of Thalassiosira pseudonana (Bacillariophyceae): broad range analysis of metabolic composition and nutritional value. J Appl Phycol. 2003;15:533-42. https://doi.org/10.1023/B: JAPH.0000004355.11837.1d.

135. Wei X, Jie D, Cuello JJ, Johnson DJ, Qiu Z, He Y. Microalgal detection by Raman microspectroscopy. TrAC - Trends Anal Chem. 2014;53:33-40. https:// doi.org/10.1016/j.trac.2013.09.012.

136. Parab TND, Tomar V. Raman spectroscopy of algae: a review. J Nanomed Nanotechnol. 2012;3. https://doi.org/10.4172/2157-7439.1000131.

137. Huang $\mathrm{G}-\mathrm{HH}$, Chen $\mathrm{G}$, Chen F. Rapid screening method for lipid production in alga based on Nile red fluorescence. Biomass Bioenergy. 2009;33:1386-92. https://doi.org/10.1016/j.biombioe.2009.05.022

138. Weiss TL, Chun HJ, Okada S, Vitha S, Holzenburg A, Laane J, et al. Raman spectroscopy analysis of botryococcene hydrocarbons from the green microalga Botryococcus braunii. J Biol Chem. 2010;285:32458-66.

139. Huang YY, Beal CM, Cai WW, Ruoff RS, Terentjev EM. Micro-Raman spectroscopy of algae: composition analysis and fluorescence background behavior. Biotechnol Bioeng. 2010;105:889-98. https://doi.org/10.1002/bit.22617.

140. Lee TH, Chang JS, Wang HY. Rapid and in vivo quantification of cellular lipids in Chlorella vulgaris using near-infrared Raman spectrometry. Anal Chem. 2013;85:2155-60

141. Li K, Cheng J, Ye Q, He Y, Zhou J, Cen K. In vivo kinetics of lipids and astaxanthin evolution in Haematococcus pluvialis mutant under 15\% CO2using Raman microspectroscopy. Bioresour Technol. 2017;244:1439-44.

142. Meksiarun $P$, Spegazzini N, Matsui H, Nakajima K, Matsuda $Y$, Satoa H. In vivo study of lipid accumulation in the microalgae marine diatom Thalassiosira pseudonana using Raman spectroscopy. Appl Spectrosc. 2015;69:45-51.

143. Sharma SK, Nelson DR, Abdrabu R, Khraiwesh B, Jijakli K, Arnoux M, et al. An integrative Raman microscopy-based workflow for rapid in situ analysis of microalgal lipid bodies. Biotechnol Biofuels. 2015;8:1-14.

144. Münchberg U, Wagner L, Rohrer C, Voigt K, Rösch P, Jahreis G, et al. Quantitative assessment of the degree of lipid unsaturation in intact Mortierella by Raman microspectroscopy. Anal Bioanal Chem. 2015;407:3303-11.

145. Samek O, Zemánek $P$, Jonáš A, Telle HH. Characterization of oil-producing microalgae using Raman spectroscopy. Laser Phys Lett. 2011;8:701-9.

146. Wang T, Ji Y, Wang Y, Jia J, Li J, Huang S, et al. Quantitative dynamics of triacylglycerol accumulation in microalgae populations at single-cell resolution revealed by Raman microspectroscopy. Biotechnol Biofuels. 2014;7:1-12

147. Hosokawa M, Ando M, Mukai S, Osada K, Yoshino T, Hamaguchi HO, et al. In vivo live cell imaging for the quantitative monitoring of lipids by using raman microspectroscopy. Anal Chem. 2014;86:8224-30.

148. Urban PL, Schmid T, Amantonico A, Zenobi R. Multidimensional analysis of single algal cells by integrating microspectroscopy with mass spectrometry. Anal Chem. 2011:83:1843-9.

149. Fu D, Lu FK, Zhang X, Freudiger C, Pernik DR, Holtom G, et al. Quantitative chemical imaging with multiplex stimulated Raman scattering microscopy. J Am Chem Soc. 2012;134:3623-6.

150. He XN, Allen J, Black PN, Baldacchini T, Huang X, Huang $H$, et al. Coherent anti-stokes Raman scattering and spontaneous Raman spectroscopy and microscopy of microalgae with nitrogen depletion. Biomed Opt Express. 2012;3:2896. https://doi.org/10.1364/BOE.3.002896.

151. Cavonius L, Fink H, Kiskis J, Albers E, Undeland I, Enejder A. Imaging of lipids in microalgae with coherent anti-stokes Raman scattering microscopy. Plant Physiol. 2015;167:603-16. https://doi.org/10.1104/pp.114.252197.

152. Jaeger D, Pilger $C$, Hachmeister $H$, Oberländer $E$, Wördenweber $R$, Wichmann J, et al. Label-free in vivo analysis of intracellular lipid droplets in the oleaginous microalga Monoraphidium neglectum by coherent Raman scattering microscopy. Sci Rep. 2016;6(June):2-10. https://doi.org/10.1038/ srep35340.

153. Wu H, Volponi JV, Oliver AE, Parikh AN, Simmons BA, Singh S. In vivo lipidomics using single-cell Raman spectroscopy. Proc Natl Acad Sci. 2011; 108:3809-14. https://doi.org/10.1073/pnas.1009043108.

154. Pořizka P, Prochazková P, Prochazka D, Sládková L, Novotný J, Petrilak M, et al. Algal biomass analysis by laser-based analytical techniques-A review. Sensors (Switzerland). 2014;14:17725-52.

155. Pick U, Rachutin-Zalogin T. Kinetic anomalies in the interactions of Nile red with microalgae. J Microbiol Methods. 2012;88:189-96. https://doi.org/10. 1016/j.mimet.2011.10.008.

156. Elsey D, Jameson D, Raleigh B, Cooney MJ. Fluorescent measurement of microalgal neutral lipids. J Microbiol Methods. 2007;68:639-42.

157. Martinez V, Henary M. Nile red and Nile blue: applications and syntheses of structural analogues. Chem - A Eur J. 2016;22:13764-82.

158. Balduyck L, Veryser C, Goiris K, Bruneel C, Muylaert K, Foubert I. Optimization of a Nile red method for rapid lipid determination in autotrophic, marine microalgae is species dependent. J Microbiol Methods. 2015;118:152-8. https://doi.org/10.1016/j.mimet.2015.09.009.

159. Chen W, Sommerfeld M, Hu Q. Microwave-assisted Nile red method for in vivo quantification of neutral lipids in microalgae. Bioresour Technol. 2011; 102:135-41. https://doi.org/10.1016/j.biortech.2010.06.076.

160. Doan TTY, Obbard JP. Improved Nile red staining of Nannochloropsis sp. J Appl Phycol. 2011:23:895-901.

161. Bertozzini E, Galluzzi L, Penna A, Magnani M. Application of the standard addition method for the absolute quantification of neutral lipids in microalgae using Nile red. J Microbiol Methods. 2011;87:17-23. https://doi. org/10.1016/j.mimet.2011.06.018.

162. Sitepu IR, Ignatia L, Franz AK, Wong DM, Faulina SA, Tsui M, et al. An improved high-throughput Nile red fluorescence assay for estimating intracellular lipids in a variety of yeast species. J Microbiol Methods. 2012;91: 321-8. https://doi.org/10.1016/j.mimet.2012.09.001.

163. Ren HY, Liu BF, Kong F, Zhao L, Ren NQ. Improved Nile red staining of Scenedesmus sp. by combining ultrasonic treatment and three-dimensional excitation emission matrix fluorescence spectroscopy. Algal Res. 2015;7:115. https://doi.org/10.1016/j.algal.2014.11.007.

164. Wong DM, Nguyen TTN, Franz AK. Ethylenediaminetetraacetic acid (EDTA) enhances intracellular lipid staining with Nile red in microalgae Tetraselmis suecica. Algal Res. 2014;5:158-63. https://doi.org/10.1016/j.algal.2014.08.002.

165. Higgins BT, Thornton-Dunwoody A, Labavitch JM, Vandergheynst JS. Microplate assay for quantitation of neutral lipids in extracts from microalgae. Anal Biochem. 2014;465:81-9. https://doi.org/10.1016/j.ab.2014.07.020.

166. Cooper MS, Hardin WR, Petersen TW, Cattolico RA. Visualizing "green oil" in live algal cells. J Biosci Bioeng. 2010;109:198-201. https://doi.org/10.1016/j. jbiosc.2009.08.004

167. Benito V, Goñi-de-Cerio F, Brettes P. BODIPY vital staining as a tool for flow cytometric monitoring of intracellular lipid accumulation in Nannochloropsis gaditana. J Appl Phycol. 2014;27:233-41.

168. Govender T, Ramanna L, Rawat I, Bux F. BODIPY staining, an alternative to the Nile red fluorescence method for the evaluation of intracellular lipids in microalgae. Bioresour Technol. 2012;114:507-11. https://doi.org/10.1016/j. biortech 2012.03 .024

169. Brennan L, Blanco Fernández A, Mostaert AS, Owende P. Enhancement of BODIPY505/515lipid fluorescence method for applications in biofueldirected microalgae production. J Microbiol Methods. 2012;90:137-43. https://doi.org/10.1016/j.mimet.2012.03.020.

170. Back A, Rossignol T, Krier F, Nicaud JM, Dhulster P. High-throughput fermentation screening for the yeast Yarrowia lipolytica with real-time monitoring of biomass and lipid production. Microb Cell Factories. 2016:15:1-12.

171. De la Jara A, Molina C, Martel A, Molina C, Nordströn L, De la Rosa V, et al. Flow cytometric determination of lipid content in a marine dinoflagellate, Crypthecodinium cohnii. J Appl Phycol. 2003;15:433-8. 
172. Harchouni S, Field B, Menand B. AC-202, a highly effective fluorophore for the visualization of lipid droplets in green algae and diatoms. Biotechnol Biofuels. 2018;11:1-9. https://doi.org/10.1186/s13068-018-1117-9.

173. Kim HS, Guzman AR, Thapa HR, Devarenne TP, Han A. A droplet microfluidics platform for rapid microalgal growth and oil production analysis. Biotechnol Bioeng. 2016;113:1691-701.

174. Lee DH, Bae CY, Han Jl, Park JK. In situ analysis of heterogeneity in the lipid content of single green microalgae in alginate hydrogel microcapsules. Anal Chem. 2013;85:8749-56.

175. Xie B, Stessman D, Hart JH, Dong H, Wang Y, Wright DA, et al. Highthroughput fluorescence-activated cell sorting for lipid hyperaccumulating Chlamydomonas reinhardtii mutants. Plant Biotechnol J. 2014;12:872-82.

176. Terashima M, Freeman ES, Jinkerson RE, Jonikas MC. A fluorescenceactivated cell sorting-based strategy for rapid isolation of high-lipid Chlamydomonas mutants. Plant J. 2015:81:147-59.

177. Capus A, Monnerat M, Ribeiro LC, de Souza W, Martins JL, Sant'Anna C. Application of high-content image analysis for quantitatively estimating lipid accumulation in oleaginous yeasts with potential for use in biodiesel production. Bioresour Technol. 2016;203:309-17.

178. Davis RW, Jones HDT, Collins AM, Ricken JB, Sinclair MB, Timlin JA, et al. Label-free measurement of algal triacylglyceride production using fluorescence hyperspectral imaging. Algal Res. 2014;5:181-9. https://doi.org/ 10.1016/j.algal.2013.11.010.

179. Kimura K, Yamaoka M, Kamisaka Y. Rapid estimation of lipids in oleaginous fungi and yeasts using Nile red fluorescence. J Microbiol Methods. 2004;56: 331-8.

180. Chen W, Zhang C, Song L, Sommerfeld M, Hu Q. A high throughput Nile red method for quantitative measurement of neutral lipids in microalgae. J Microbiol Methods. 2009;77:41-7. https://doi.org/10.1016/j.mimet.2009.01.001

181. Gusbeth AC, Eing C, Göttel M, Sträßner R, Frey W. Fluorescence diagnostics for lipid status monitoring of microalgae during cultivation. Int J Renew Energy Biofuels. 2016;2016:1-10. https://doi.org/10.5171/2016.899698.

182. Sun T, Gawad S, Bernabini C, Green NG, Morgan H. Broadband single cell impedance spectroscopy using maximum length sequences: theoretical analysis and practical considerations. Meas Sci Technol. 2007;18:2859-68.

183. Higashiyama K, Sugimoto T, Yonezawa T, Fujikawa S, Asami K. Dielectric analysis for estimation of oil content in the mycelia of Mortierella alpina. Biotechnol Bioeng. 1999;65:537-41.

184. Wu Y, Huang C, Wang L, Miao X, Xing W, Cheng J. Electrokinetic system to determine differences of electrorotation and traveling-wave electrophoresis between autotrophic and heterotrophic algal cells. Colloids Surfaces A Physicochem Eng Asp. 2005;262:57-64.

185. Deng YL, Chang JS, Juang YJ. Separation of microalgae with different lipid contents by dielectrophoresis. Bioresour Technol. 2013;135:137-41. https:// doi.org/10.1016/j.biortech.2012.11.046.

186. Bono MS, Ahner BA, Kirby BJ. Detection of algal lipid accumulation due to nitrogen limitation via dielectric spectroscopy of Chlamydomonas reinhardtii suspensions in a coaxial transmission line sample cell. Bioresour Technol. 2013;143:623-31. https://doi.org/10.1016/j.biortech.2013.06.040.

187. Chen Y, Vaidyanathan S. A simple, reproducible and sensitive spectrophotometric method to estimate microalgal lipids. Anal Chim Acta. 2012;724:67-72. https://doi.org/10.1016/j.aca.2012.02.049.

188. Saifer A, Feldman NI. The photometric determination of gangliosides with the sulfo-phospho-vanillin reaction. J Lipid Res. 1971;12:112-5.

189. Knight JA, Anderson S, Rawle JM. Chemical basis of the Sulfo-phospho-vanillin Reactionfor EstimatingTotal serum lipids. Clin Chem. 1972;18:199-202.

190. Anschau A, Caruso CS, Kuhn RC, Franco T. Validation of the sulfophosphovanillin (SPV) method for the determination of lipid content in oleaginous microorganisms. Brazilian J Chem Eng. 2017;34:19-27.

191. Byreddy AR, Gupta A, Barrow CJ, Puri M. A quick colorimetric method for total lipid quantification in microalgae. J Microbiol Methods. 2016;125:28-32. https://doi.org/10.1016/j.mimet.2016.04.002.

192. Wawrik B, Harriman BH. Rapid, colorimetric quantification of lipid from algal cultures. J Microbiol Methods. 2010;80:262-6. https://doi.org/10.1016/j. mimet.2010.01.016.

193. Cheng Y-SS, Zheng Y, VanderGheynst JS. Rapid quantitative analysis of lipids using a colorimetric method in a microplate format. Lipids. 2011;46:95-103. https://doi.org/10.1007/s11745-010-3494-0.

194. Mishra SK, Suh WI, Farooq W, Moon M, Shrivastav A, Park MS, et al. Rapid quantification of microalgal lipids in aqueous medium by a simple colorimetric method. Bioresour Technol. 2014;155:330-3. https://doi.org/10. 1016/j.biortech.2013.12.077.

195. Kim Y, Jeong SN, Kim B, Kim DP, Cho YK. Rapid and automated quantification of microalgal lipids on a spinning disc. Anal Chem. 2015:87:7865-71.

196. Anschau A, Caruso CS, Kuhn RC, Franco TT, Byreddy AR, Gupta A, et al. Color holographic microscope for monitoring lipids in microalgae. J Microbiol Methods. 2017;31:262-6. https://doi.org/10.1016/j.biortech.2013.12.077.

197. Samek O, Jonáš A, Pilát Z, Zemánek P, Nedbal L, Tríska J, et al. Raman microspectroscopy of individual algal cells: sensing unsaturation of storage lipids in vivo. Sensors. 2010;10:8635-51.
Ready to submit your research? Choose BMC and benefit from:

- fast, convenient online submission

- thorough peer review by experienced researchers in your field

- rapid publication on acceptance

- support for research data, including large and complex data types

- gold Open Access which fosters wider collaboration and increased citations

- maximum visibility for your research: over $100 \mathrm{M}$ website views per year

At $\mathrm{BMC}$, research is always in progress.

Learn more biomedcentral.com/submissions 